\title{
Civil Partnerships Five Years On
}

Helen Ross ${ }^{\star 1}$, Karen Gask ${ }^{* 1}$ and Ann Berrington ${ }^{* 2}$

*1 Office for National Statistics

*2 ESRC Centre for Population Change, School of Social Sciences, University of Southampton

\section{Abstract}

The Civil Partnership Act 2004, which came into force in December 2005 allowing same-sex couples in the UK to register their relationship for the first time, celebrated its fifth anniversary in December 2010. This article examines civil partnership in England and Wales, five years on from its introduction. The characteristics of those forming civil partnerships between 2005 and 2010 including age, sex and previous marital/civil partnership status are examined. These are then compared with the characteristics of those marrying over the same period. Further comparisons are also made between civil partnership dissolutions and divorce. The article presents estimates of the number of people currently in civil partnerships and children of civil partners. Finally the article examines attitudes towards same-sex and civil partner couples both in the UK and in other countries across Europe. 


\section{Introduction}

The Civil Partnership Act $2004^{1}$, which allowed same-sex couples in the UK to register their relationship for the first time, celebrated its fifth anniversary in December 2010.

The Act came into force in the UK on 5 December 2005, the first day that couples could give notice of their intention to form a civil partnership. Couples could first form and register a partnership on 19 December in Northern Ireland, 20 December in Scotland and 21 December in England and Wales. A civil partnership is formed when the second civil partner signs the relevant documents ${ }^{2}$. This is different from a civil marriage which is formed when the couple exchange spoken words.

The Act created a new legally recognised relationship of civil partner, giving same-sex couples aged 16 and over the opportunity to gain legal recognition in the UK for their relationship. Couples who register as civil partners gain a package of rights and responsibilities including tax and benefits, ability to apply for parental responsibility for their civil partner's child and the full range of financial orders available to a married couple on divorce.

In the UK a civil partnership can only be formed between two same-sex partners; however, in other countries this may not be the case. Many European countries moved to allow same-sex couples to register their union as a civil partnership during the 1990s (starting with Denmark in 1989). A smaller number of countries have gone further and legalised same-sex marriage including the Netherlands (2001); Belgium (2003); Spain (2005); Norway (2009) and Sweden (2009)

Some countries have also enacted legislation giving same-sex couples adoption rights ${ }^{5}$. In England and Wales the Adoption and Children Act $2002^{6}$ (which came into full effect in December 2005) permitted same-sex couples to jointly adopt children. Similar legislation has been enacted for Scotland. Changes in legislation can both promote and respond to changes in public opinion and it is not surprising that more accepting attitudes towards same-sex partnerships are found in countries where the legislation has been made more equal.

This article focuses on civil partnerships in England and Wales. Firstly, trends in the numbers of civil partnerships registered between 2005 and 2010 are outlined. The distribution of men and women entering into civil partnerships by age and previous partnership status are examined and comparisons are made between the age profiles of those entering into a civil partnership and those entering a marriage. The article then discusses the regional distribution of the number of civil partnerships before presenting trends in the number of civil partnership dissolutions by sex and age between 2007 and 2010. The subsequent section outlines estimates of the stock of men and women currently living in a civil partnership. The final section explores trends and differentials in attitudes to same sex couples and civil partnerships in the UK and in other European Countries.

\section{Civil Partnership Formations}

\section{Number of civil partnerships}

The total number of civil partnerships formed in England and Wales between the Act coming into force in December 2005 and the end of 2010 is $42,778^{7}$. This is equivalent to 85,556 civil partners. This is much higher than the number estimated in the Regulatory Impact Assessment on the Civil 
Partnership Act $2004^{8}$ where it was suggested that by 2010 the estimated likely take-up of civil partnerships in Great Britain would be between 11,000 and 22,000 people in civil partnerships ${ }^{9}$.

Figure 1 shows the number of civil partnerships formed in England and Wales between December 2005 and the end of 2010 by quarter of occurrence. Quarterly data are more informative than annual data in the first few years after the legislation was implemented as significant changes during the first year can be seen. Initially, thousands of couples chose to show their commitment by forming a civil partnership, but the numbers have since fallen.

\section{Figure $1 \quad$ Number of civil partnerships formed in England and Wales by quarter of occurrence, 2005-2010}

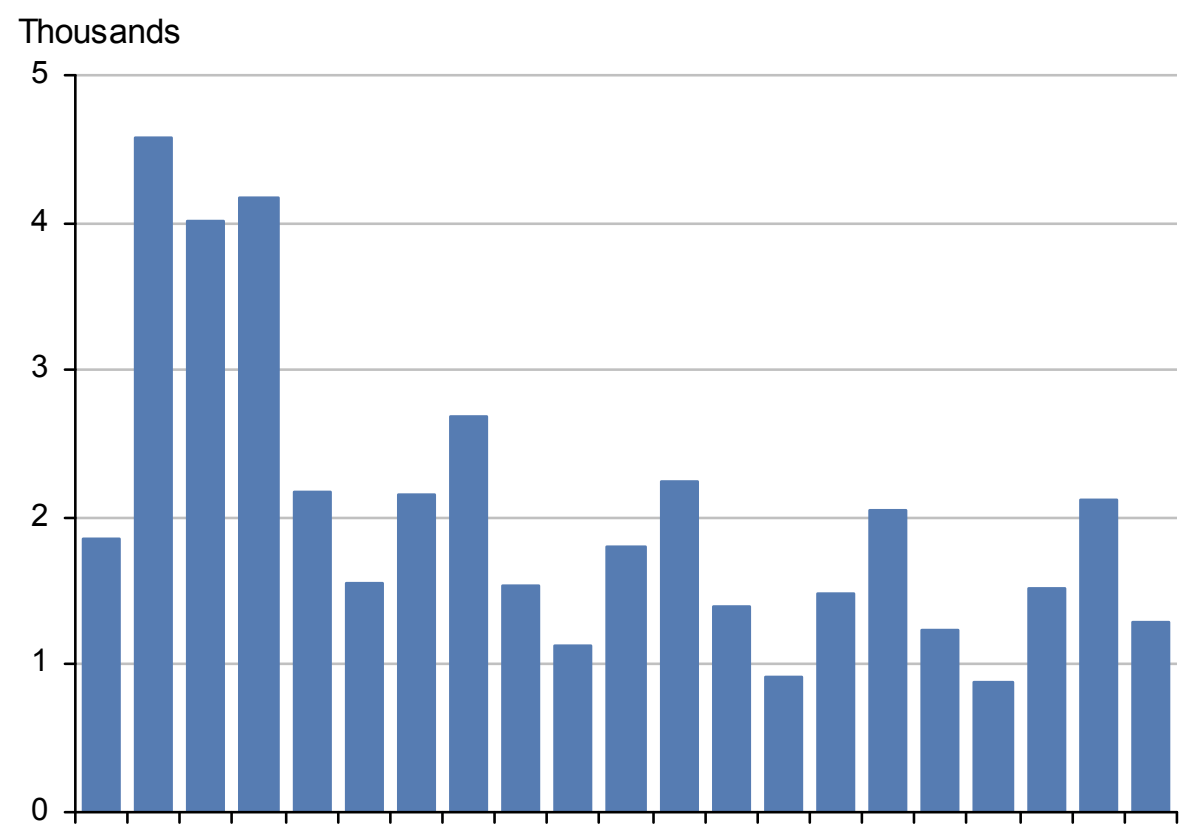

Note: * The Civil Partnership Act 2004 came into force on 5 December 2005 and allowed partnerships to be registered from 21 December 2005.

Source: Office for National Statistics

There were 1,857 civil partnerships formed in England and Wales in the 11 days available in December 2005 and 14,943 throughout 2006. By 2010, only 5,804 civil partnerships were formed throughout the year, a large decrease since 2006.

The number of partnerships in England and Wales peaked at 4,579 in the first quarter of 2006 and remained over four thousand in the second and third quarters, but fell to 2,175 in the fourth quarter. There were 7,929 civil partnerships formed in England and Wales in 2007, a decrease of 47 per cent compared with 2006. This large decrease may reflect the fact that many same-sex couples in long standing relationships took advantage of the opportunity to formalise their relationship in 2006, the first full year in which civil partnerships could be formed.

The number of civil partnerships decreased again in 2008 and by 2009 had fallen to 5,687 partnerships. Numbers in 2010 increased slightly by 2.1 per cent compared with 2009 . This small increase may indicate that a steady level has been reached. From 2007 onwards a seasonal 
pattern has emerged whereby numbers registering a civil partnership are highest in the third quarter (July to September) which is similar to the seasonal trend in marriages.

The recent decline in numbers is perhaps inevitable after many took immediate advantage of the new legislation. Similar trends have also been seen in other European countries, for example Norway and Sweden, where same-sex partnership laws became effective in August 1993 and January 1995 respectively. In these countries the initial increase in numbers was followed by a few years of stable trends at a lower level and a subsequent increase in more recent years ${ }^{10}$.

\section{Civil partnership rates ${ }^{11}$}

Civil partnerships formed in England and Wales in December 2005 equated to an annual rate of 8.1 men per 1,000 unmarried men aged 16 and over registering a partnership, and a rate of 3.7 for women (Table 1). By 2006, the rate had decreased to 1.8 per 1,000 unmarried men and 1.0 per 1,000 unmarried women aged 16 and over. By 2010, provisional rates had fallen further and less than one person (0.5) per 1,000 unmarried adults aged 16 and over entered into a civil partnership in England and Wales ${ }^{12}$.

\section{Table 1 Civil partnership rates ${ }^{11,12}$ by year and sex, England and Wales}

\begin{tabular}{lll}
\hline Year & Male & Female \\
\hline 2005 & 8.1 & 3.7 \\
2006 & 1.8 & 1.0 \\
2007 & 0.8 & 0.6 \\
2008 & 0.7 & 0.5 \\
2009 & 0.5 & 0.5 \\
$2010^{p}$ & 0.5 & 0.5 \\
\hline
\end{tabular}

Note: $p$ Rates for 2010 are provisional

Source: Office for National Statistics

\section{Civil partnerships by sex}

Although more men than women formed civil partnerships in England and Wales in each year up until 2009, the numbers of male and female partnerships have been converging (Figure 2). In December 2005 and the first quarter of 2006, 66 per cent of civil partnerships were to male couples. By the last quarter of 2006 this proportion had decreased to 57 per cent. Only 49 per cent of partnerships formed in 2010 were to male couples.

Out of the total 42,778 civil partnerships formed in England and Wales between the legislation coming into effect and the end of 2010, 56 per cent (23,968 partnerships) have been to male couples. 


\section{Figure $2 \quad$ Number of civil partnerships formed by sex, England and Wales, 2005-2010}

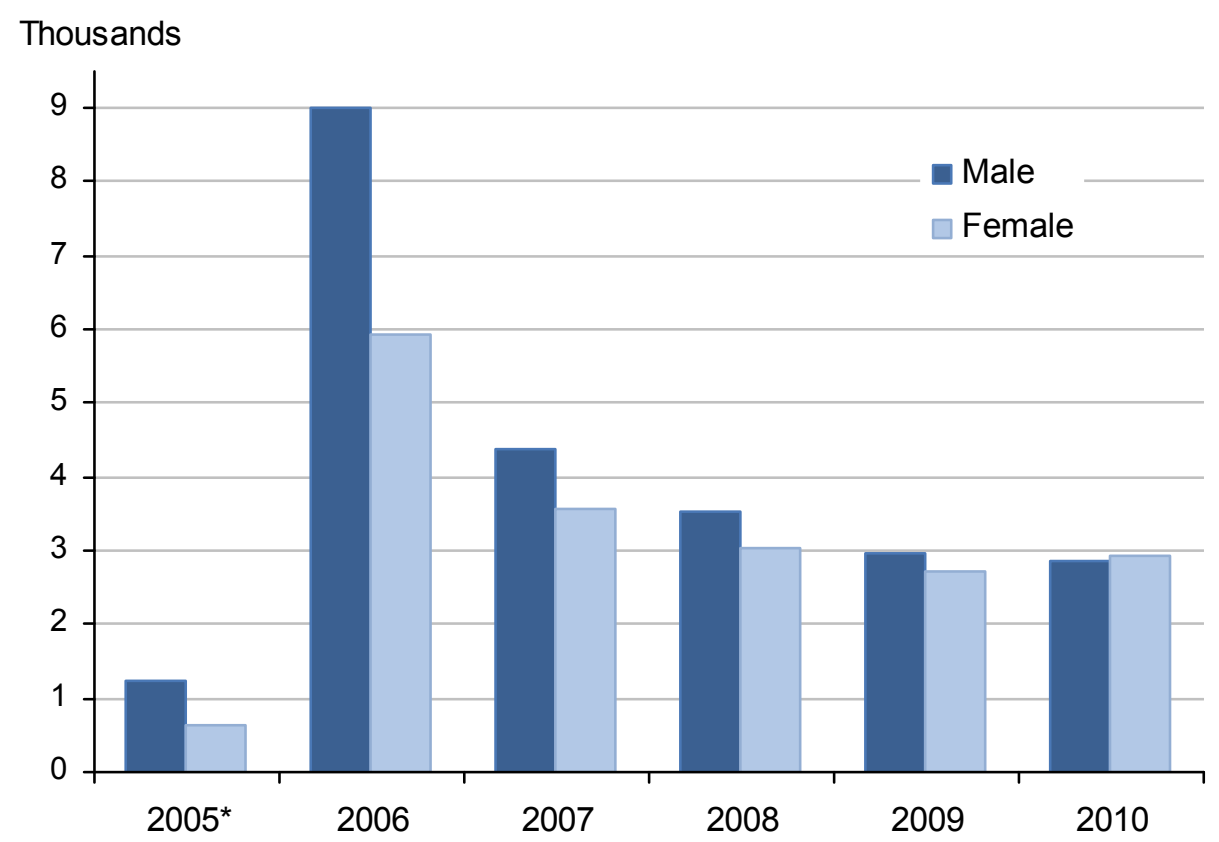

Note: * The Civil Partnership Act 2004 came into force on 5 December 2005

Source: Office for National Statistics

\section{Age distribution}

The age distribution of men and women forming civil partnerships has changed considerably over the last five years (Figure 3). In 2006, more than a third of all men (38 per cent) and over a quarter of all women (27 per cent) were aged 50 and over at the date of formation. Nineteen per cent of male partners in 2006 were aged under 35 compared with 24 per cent of female partners.

By 2010 the age profile of men and women entering civil partnerships had shifted towards younger ages. In particular the percentage of people entering a civil partnership aged over 50 in 2010 was about 20 per cent for men and 14 per cent for women (see Figure 3).

In 2010 the most common age groups for men to form a civil partnership were 35 to 39 and 40 to 44 years (with equal numbers of men). For women the most common age group was 35 to 39 years. This is slightly younger than 2006 when it was 40 to 44 years for both men and women.

Men are on average older than women when they enter into a civil partnership. The average (mean) age at formation in England and Wales in December 2005 was 54.0 years for men and 46.3 years for women ${ }^{13}$.

The mean age at formation for male civil partners has remained higher than for female civil partners for all years, although it has fallen for both sexes year on year (Table 2). For men, the average age fell from 47.1 years in 2006 to 40.7 years in 2010 and for women from 43.7 years in 2006 to 38.3 years in 2010 . The decline in average age was expected as many same-sex couples 
in long-standing relationships formed their civil partnership in late 2005 and 2006, soon after the legislation was implemented.

\section{Figure 3 Percentage of people forming civil partnerships by age group, England and Wales, 2006 and 2010}

\section{Males}

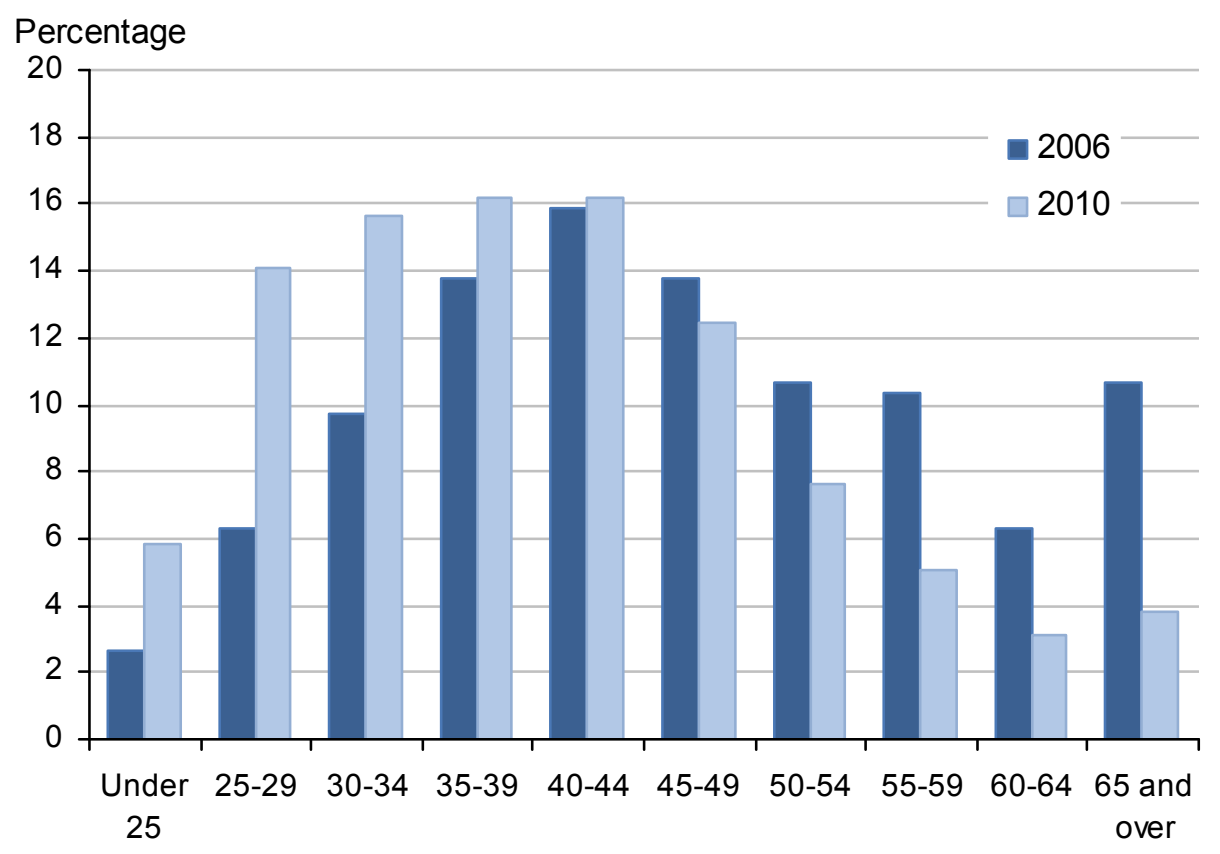

\section{Females}

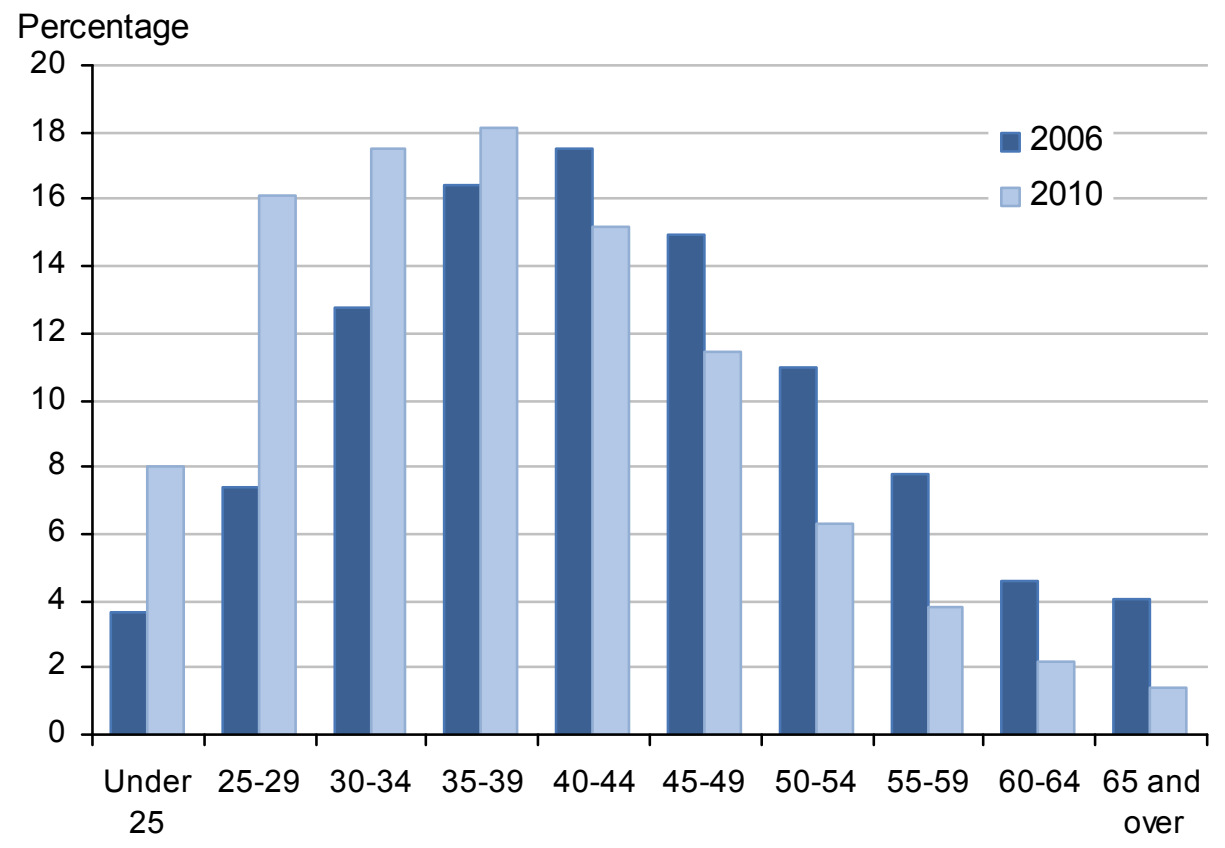

Source: Office for National Statistics

Large age differences between partners in England and Wales are more common in partnerships between men than between women (Figure 4). This pattern is also seen in Norway and Sweden ${ }^{10}$. 
Fifty-seven per cent of female civil partnerships in England and Wales in 2010 were formed by women with an age differences of less than five years compared with 46 per cent of male partnerships. In contrast, 29 per cent of male civil partnerships were formed by men with an age difference of 10 or more years compared with 16 per cent of female civil partnerships.

\section{Table 2 Mean age $^{13}$ at civil partnership formation by year and sex, England and Wales}

\begin{tabular}{lll}
\hline Year & Male & Female \\
\hline 2005 & 54.0 & 46.3 \\
2006 & 47.1 & 43.7 \\
2007 & 42.9 & 41.2 \\
2008 & 41.8 & 39.9 \\
2009 & 41.2 & 38.9 \\
2010 & 40.7 & 38.3 \\
\hline
\end{tabular}

\section{Comparing the age profile of partners at civil partnership and marriage}

We can compare the demographic characteristics of partners involved in civil partnerships and marriages. Civil partners are typically older than brides and grooms when they register their relationships. The average age of those who have registered a civil partnership so far is considerably higher than that for marriage, as those who have been waiting for years to have the opportunity to formalize their relationship have finally been able to do so.

\section{Figure 4 Distribution of age differences between partners at marriage and civil partnership, England and Wales}

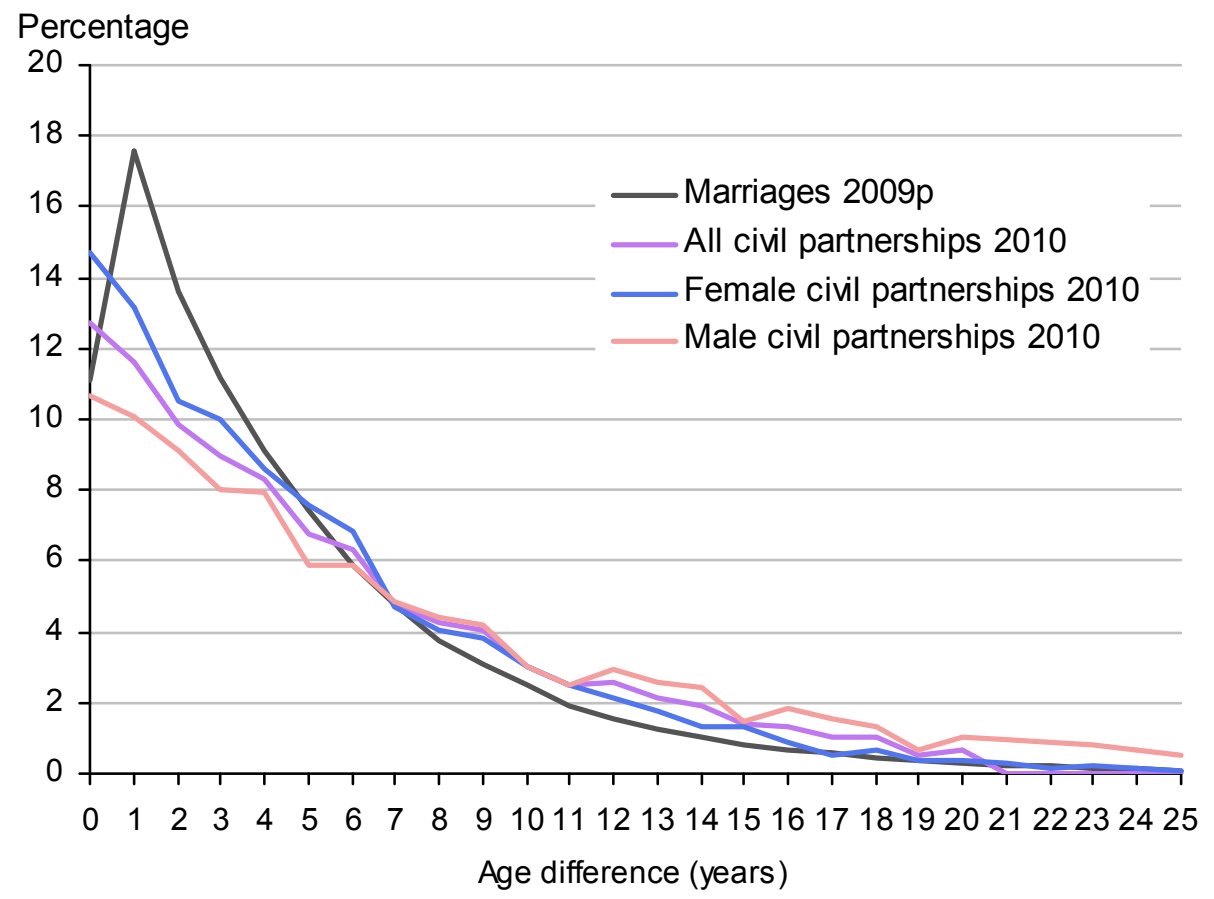

Notes:

p Figures for marriages for 2009 are provisional

Figures are shown as a percentage of all marriages/civil partnerships in that year. There were 231,490 marriages in 2009 and 5,804 civil partnerships in 2010.

Age differences larger than 25 years are not shown, but are uncommon.

Source: Office for National Statistics 
The mean age of all men who registered a civil partnership in England and Wales in 2010 was 40.7 years compared to a provisional mean age at marriage for all men in England and Wales in 2009 (the latest year for which data are available) of 36.3 years.

Again when comparing brides to female civil partners it is seen that female civil partners are older, 38.3 years on average in 2010 , compared to a provisional figure of 33.7 years for the mean age at marriage for all brides in 2009.

In Figure 4 we examine the absolute difference in age of the partners in marriages from 2009 and civil partnerships from 2010. The majority of both marriages and civil partnerships were formed by partners of similar ages. The most common age difference between partners marrying in 2009 was 1 year (almost 18 per cent of all marriages) whereas for civil partners in 2010 it was 0 years (13 per cent of all civil partnerships). However, age differences of greater than five years are more common in civil partnerships than in marriages. Seventy per cent of all marriages in 2009 were to partners whose age difference was five years or less compared to only 58 per cent of all civil partnerships in 2010. The proportion of all civil partnerships in 2010 where the age difference between partners was greater than 10 years was 19 per cent, compared with 10 per cent of marriages in 2009.

\section{Previous partnership status}

Over the past five years, 73 per cent of all civil partnerships formed in England and Wales were to couples where both partners were single (see box 1 for definitions). This proportion is higher for men: 80 per cent of all male civil partnerships formed since 2005 were between two single men, but only 63 per cent of female civil partnerships were between two single women.

\section{Box 1 Previous partnership status definitions}

The previous partnership status of a civil partner is defined as their marital or civil partnership status prior to giving notice of their intention to form a civil partnership.

A person wishing to register a civil partnership in the UK must either be:

- single (never married and never formed a civil partnership) or

- have previously been in a marriage or civil partnership which has been terminated either by divorce/dissolution or annulment or by the death of the spouse or civil partner

The majority (79 per cent) of male civil partnerships formed in England and Wales in 2010 were between two single men and 19 per cent involved a single man forming a civil partnership with a man who had previously been in a marriage or civil partnership. More than two out of three (67 per cent) female civil partnerships in 2010 were between two single women and over a quarter (27 per cent) involved a single woman forming a civil partnership with a woman who had previously been in a marriage or civil partnership. A similar pattern is observed in earlier years. 
Among the civil partnerships taking place in 2010, 11 per cent of men and 19 per cent of women were in their second legally recognised relationship following the dissolution of a previous marriage or civil partnership (Figure 5). These were similar to the proportions for previous years.

The age distribution of men and women forming a partnership in England and Wales is associated with previous partnership status. Partners who are single are generally younger than those who had previously been in a marriage or civil partnership. For example, in 2010, 71 per cent of widowed men forming partnerships were aged 50 and over compared to only 17 per cent of single men.

\section{Figure 5 Previous partnership status of men and women forming a civil partnership in 2010, England and Wales}

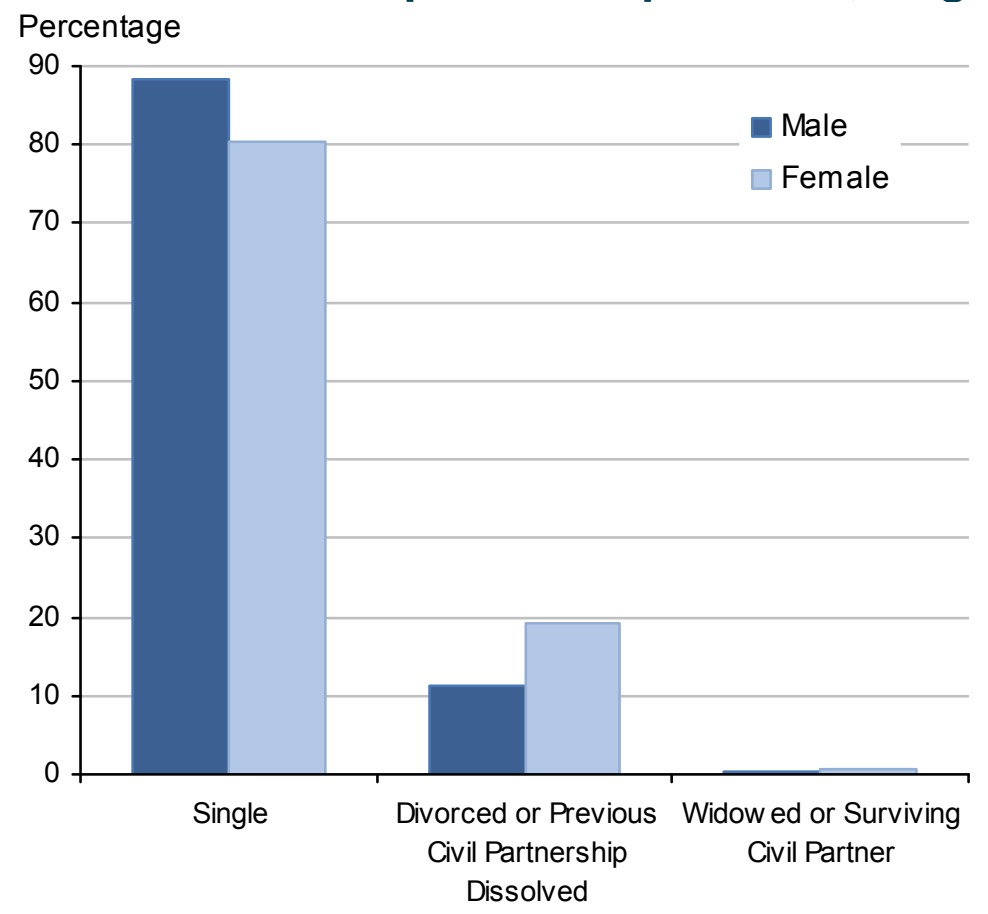

Source: Office for National Statistics

\section{Area of formation}

The distribution of civil partnership formations across England and Wales by county, unitary authority, metropolitan district and London borough is not evenly spread (Figures 6 and 7). A couple may choose to register their civil partnership in any registry office or approved location across the UK. Data by area represent the area in which the partnership was registered and is not necessarily a good indicator of the area of usual residence.

The local authorities with the largest numbers of civil partnership registrations in both 2006 and 2010 were Brighton and Hove unitary authority and the London borough of Westminster.

London has been the most popular region in England and Wales in which to register a civil partnership every year since the legislation was introduced in 2005. In 2010 just over a quarter (27 per cent) of all civil partnerships were registered there. It was also the region with the highest proportion of male civil partnerships compared with female (70 per cent male). 
Figure 6 Number of Civil Partnerships: by area of formation, 2006*

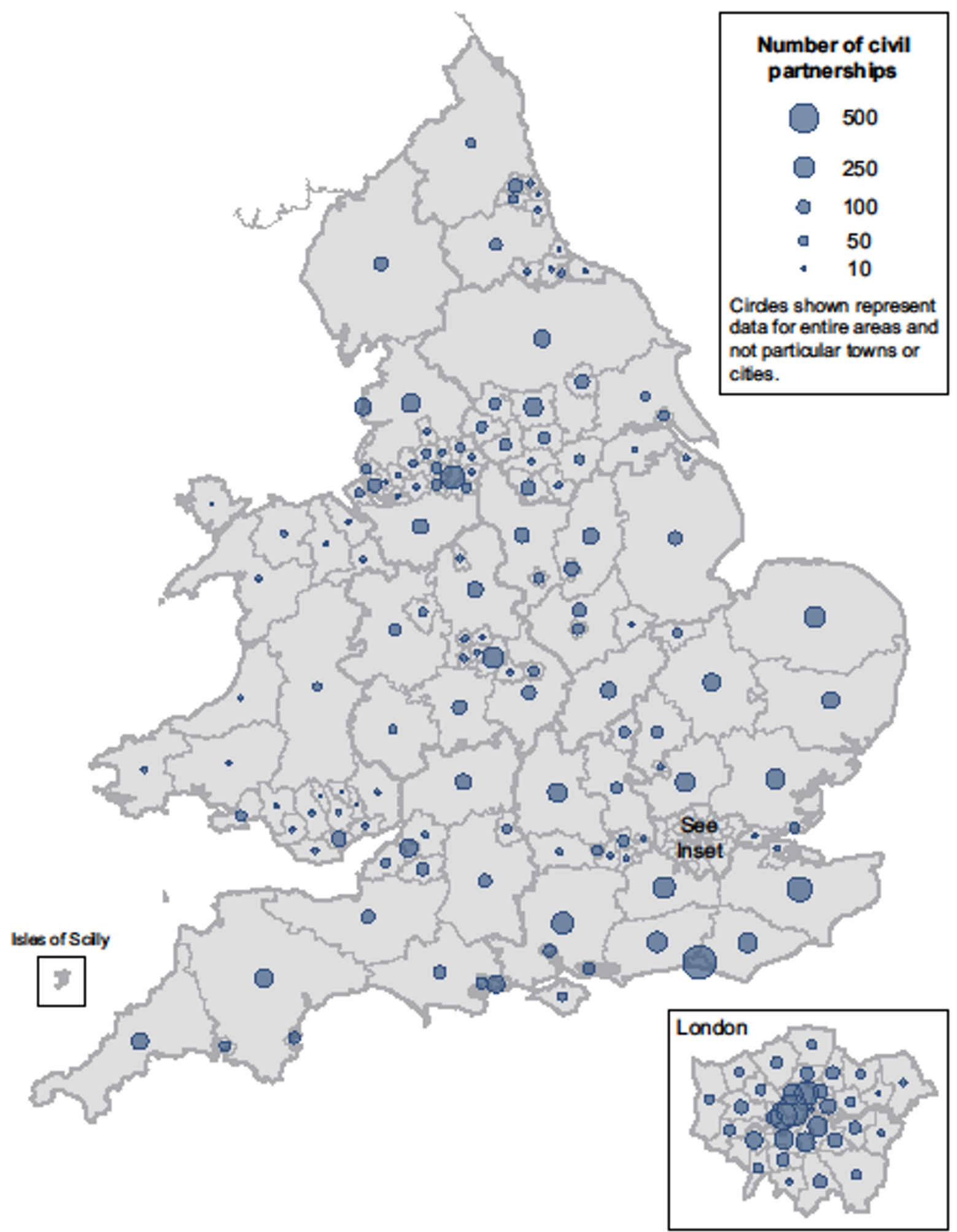

${ }^{*}$ Notes:

Counties, unitary authorities, metropolitan districts and London boroughs shown are effective from 1 January 2010.

Data for the Isles of Scilly and for Cornwall have been combined for disclosure purposes.

Source: Office for National Statistics

Contains National Statistics data ( Crown copyright and database right 2011

Contains Ordnance Survey data @ Crown copyright and database right 2011 
Figure 7 Number of Civil Partnerships: by area of formation, 2010*

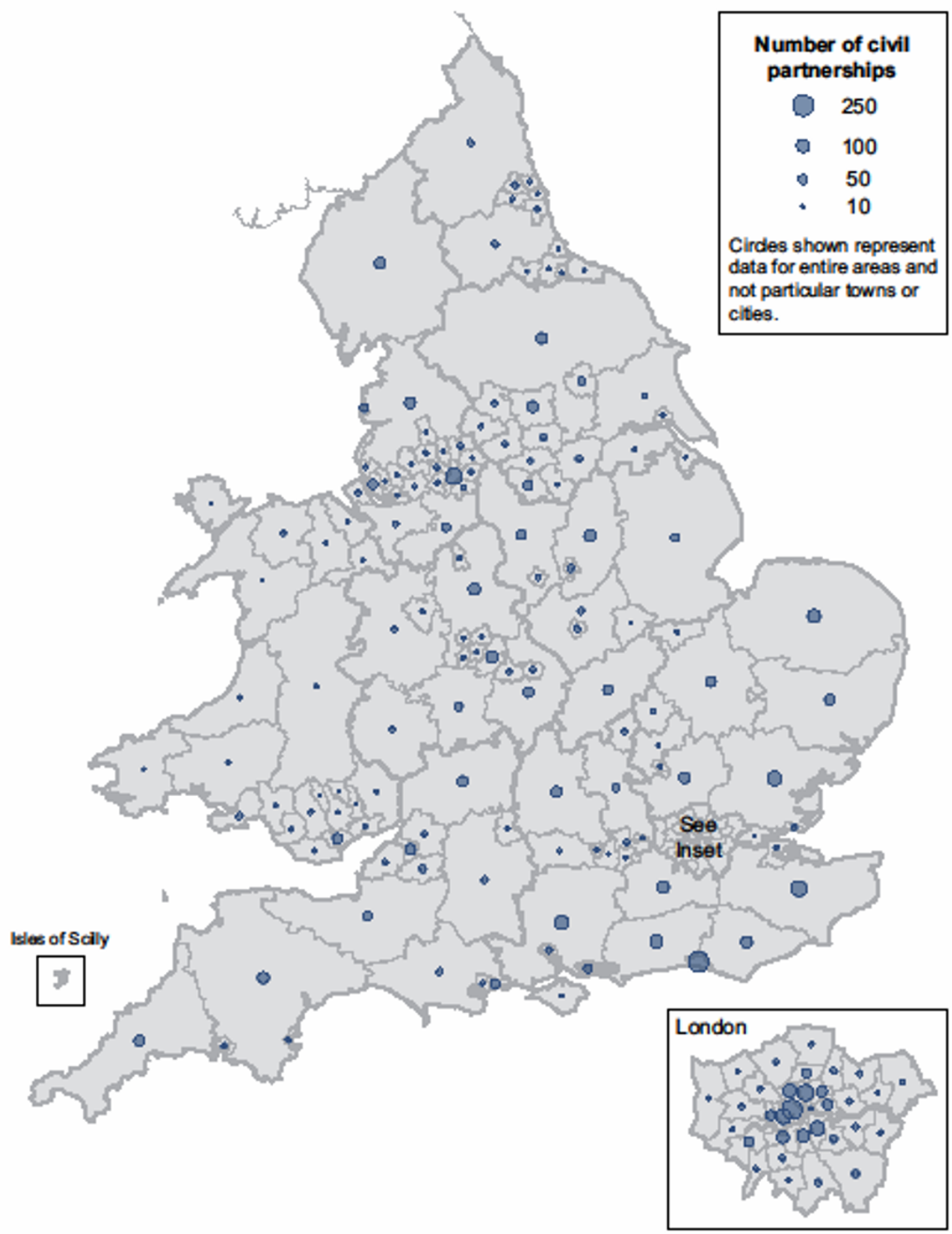

${ }^{*}$ Notes:

Counties, unitary authorities, metropolitan districts and London boroughs shown are effective from 1 January 2010.

Data for the Isles of Scilly and for Cornwall have been combined for disclosure purposes.

Source: Office for National Statistics

Contains National Statistics data ( Crown copyright and database right 2011

Contains Ordnance Survey data @ Crown copyright and database right 2011 
Thirty per cent of all male civil partnerships in England and Wales took place in London in 2005, and this proportion has been steadily rising, reaching 38 per cent in 2010. In contrast this region accounted for only 14 per cent of the usually resident adult male population of England and Wales in $2010^{14}$. The South East, with 16 per cent of all male civil partnerships in 2010, was the second most popular region.

The number of female civil partnerships in England and Wales was highest in the South East region in all years 2005 to 2010, with 18 per cent of all women choosing to register their civil partnership there in 2010. London has consistently been the second most popular area for women to form a civil partnership.

\section{Civil Partnership Dissolutions ${ }^{15}$}

\section{Number of civil partnership dissolutions}

With the implementation of the Civil Partnership Act came legislation not only on the formation of civil partnerships but also on their dissolution. To obtain a civil partnership dissolution in England and Wales, a couple must have been in either a registered civil partnership or a recognised foreign same-sex relationship for 12 months. Box 2 shows the possible grounds for dissolution.

\section{Box 2 Grounds for dissolution}

The only possible ground for dissolution of a civil partnership is that the partnership has broken down irretrievably. In order to establish irretrievable breakdown, the civil partner applying for the dissolution must satisfy the court of one or more of the following:

- behaviour by one civil partner which means that the other cannot reasonably be expected to live with him/her

- separation for two years with consent

- separation for five years

- desertion of one party by the other for a period of two years

Unlike divorce, adultery is not recognised as a ground for dissolution as the legal definition of adultery involves two adults of opposite sex. However unfaithfulness may be recognised as a form of unreasonable behaviour.

No civil partnership dissolutions were granted in England and Wales during 2006; however, there were 40 granted in 2007 rising to a provisional figure of 472 in 2010. Figure 8 shows how the number of dissolutions by quarter has changed since 2007. A gradual increase is seen across the years and total numbers in 2010 are almost triple those in 2008 . The total number of dissolutions in England and Wales since the Act came into force until the end of 2010 is $1,007$. 


\section{Figure $8 \quad$ Number of civil partnership dissolutions granted in England and Wales by quarter, 2007-2010}

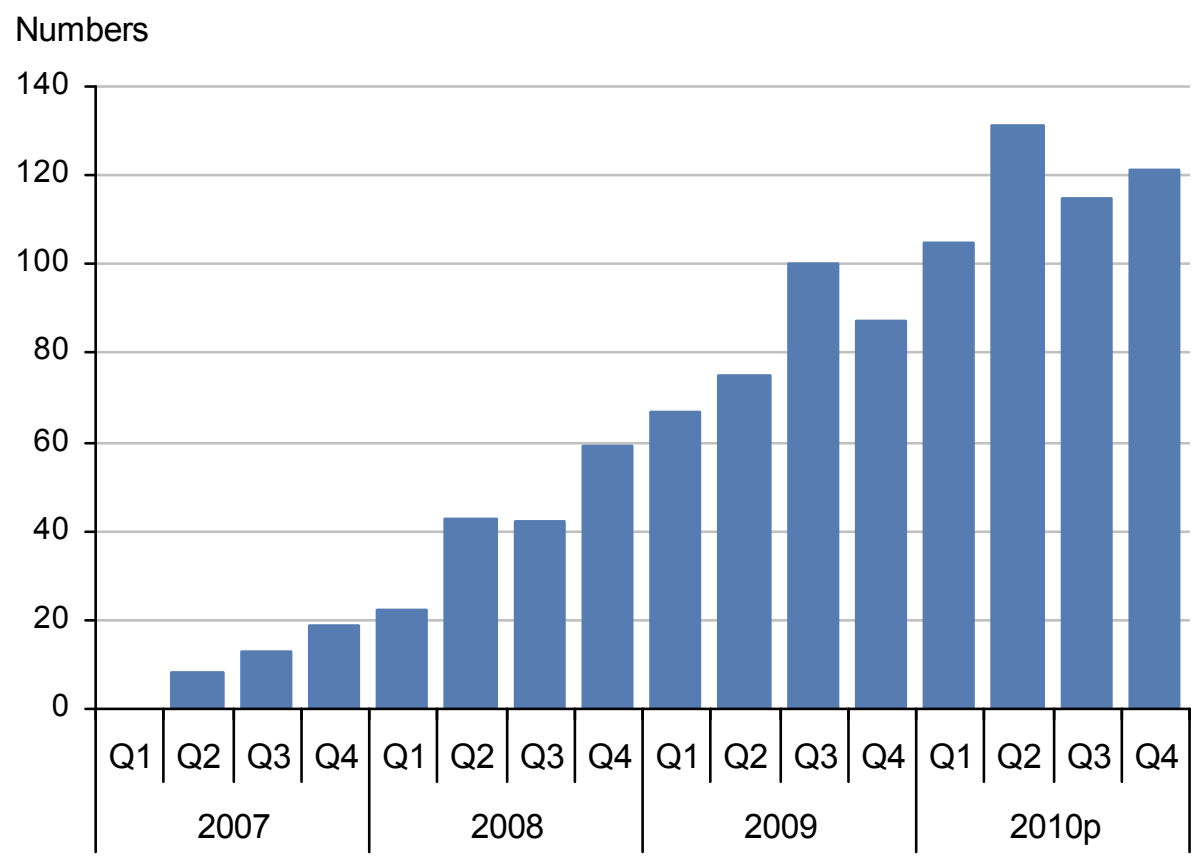

p Figures for 2010 are provisional

Source: Office for National Statistics

\section{Civil partnership dissolutions by sex}

The number of dissolutions granted varies by sex. Of all dissolutions granted in England and Wales up to the end of 2010, 62 per cent have been to female couples despite only 44 per cent of formations being to female couples. The proportion of dissolutions to female couples differs by year. In 2007, 70 per cent of dissolutions granted were to female couples whereas in 2010 this was only 60 per cent. Higher numbers of dissolutions among female than male partnerships are also seen in other countries with same-sex partnership laws, such as Norway and Sweden ${ }^{10}$.

\section{Age distribution}

The age distribution of men and women dissolving civil partnerships has remained stable year on year. The most common age group for both men and women to dissolve a civil partnership in 2010 was 35 to 39 years, compared with 2007 when it was 30 to 34 years for women and 35 to 39 years for men.

Male civil partners are on average slightly older than females when they dissolve a civil partnership. The average (mean) age at dissolution in England and Wales in 2007 was 40.5 years for men and 39.4 years for women ${ }^{13}$. This is likely to reflect the higher average age at which men form a civil partnership.

The average age at dissolution has fallen for both sexes since 2007. For men, the average age fell from 40.5 years in 2007 to 39.5 years in 2010 and for women from 39.4 years in 2007 to 37.7 years in 2010. The mean age at dissolution is similar or lower than the mean age at formation, which suggests that younger couples are more likely than older couples to dissolve their partnerships. 
Large age differences between partners dissolving a civil partnership are more frequent among men than women. Thirty-four per cent of male civil partnership dissolutions in 2010 were to men with an age difference of 10 or more years, compared with 19 per cent of female dissolutions. This is likely to reflect the age difference at formation discussed earlier.

\section{Previous partnership status}

The majority of civil partnership dissolutions in England and Wales over the last few years have been to partners whose previous partnership status at civil partnership was single. This is because the majority of civil partnership formations are to single people. Between 2007 and 2010, 84 per cent of all civil partners dissolving partnerships were single before they formed the partnership. This proportion is higher for men than women. Eighty-seven per cent of all male civil partners dissolving a partnership had been single prior to the civil partnership, compared to only 82 per cent of female partners who were single before the civil partnership. The pattern observed reflects the fact that women forming civil partnerships are less likely to be single then men forming civil partnerships (as shown in Figure 5).

\section{Figure 9 Previous partnership status of men and women dissolving a civil partnership in 2010, England and Wales}

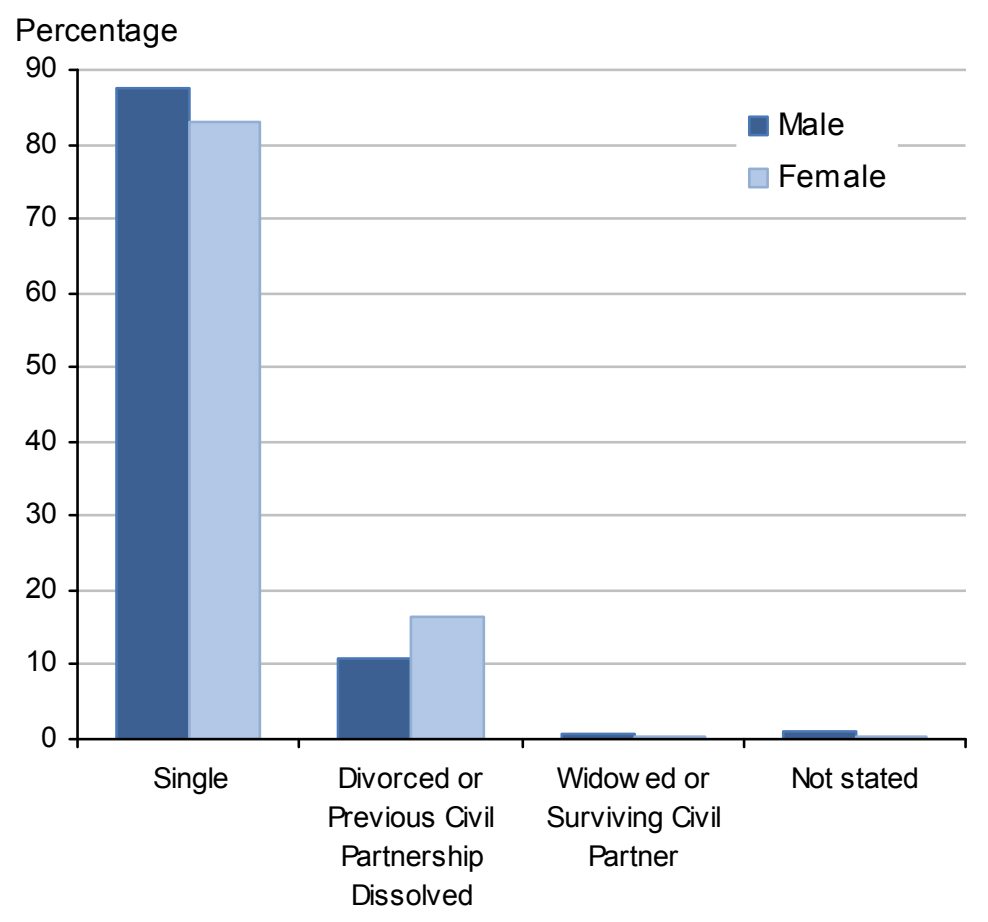

Source: Office for National Statistics

The overall proportion of people dissolving a civil partnership whose previous partnership status was 'divorced' or 'previous civil partnership dissolved' has risen slightly from 13 per cent in 2007 to 14 per cent in 2010. This again differed between men and women. Among those dissolving a civil partnership in 2010, a higher proportion of women (17 per cent) than men (11 per cent) were dissolving at least their second legally recognised relationship. This pattern is seen in all years 
except 2007 when the proportions of men and women dissolving at least their second legally recognised relationship were equal.

By comparing Figures 5 and Figure 9 it is seen that the proportions of men and women forming civil partnerships by previous partnership status are very similar to those dissolving civil partnerships.

\section{Comparing civil partnership dissolutions with divorces}

Partners dissolving a civil partnership are typically younger than brides and grooms when they divorce, despite the average age at marriage being lower than that at civil partnership.

In 2007 the mean age at civil partnership dissolution in England and Wales was 40.5 years for men and 39.4 years for women but by 2010 it had fallen to 39.5 years for men and 37.7 years for women. This compares to a mean age at divorce in 2009 (the latest year for which data are available) of 44.0 years for men and 41.5 years for women.

These differences may relate to differences in previous partnership status between those divorcing and those dissolving a civil partnership. In 2010, 14 per cent of all people dissolving a civil partnership had previously been in a marriage/civil partnerships which had ended in divorce/dissolution, compared with 20 per cent of all people divorcing in 2009.

Larger age differences between partners are more common in couples dissolving a civil partnership than those divorcing. The majority of both divorces and civil partnership dissolutions in 2010 occurred to partners of similar ages. Seventy per cent of all divorces in 2009 were to partners whose age difference was five years or less compared to only 52 per cent of all civil partnership dissolution in 2010. The proportion of all civil partnership dissolutions in 2010 where the age difference between partners was greater than 10 years was 21 per cent (100 dissolutions) compared with 9.7 per cent of divorces in 2009 (11,016 divorces). The patterns observed reflect the fact that there is a greater tendency for larger age differences to exist between partners in civil partnerships (as shown in Figure 4).

\section{Percentage of civil partnerships that have ended in dissolution}

The percentage of civil partnership formations which end in dissolution by a given anniversary can be compared with the percentage of marriages which end in divorce by a given anniversary. This analysis is limited because only four years of civil partnership dissolution data are available ${ }^{16}$. Also it does not take into account that marriages and civil partnerships can end by the death of a partner, not just by divorce or dissolution.

Tables $\mathbf{3}$ and $\mathbf{4}$ show that marriages are more likely to end in divorce than civil partnerships are to end in dissolution and that this trend increases as the number of years since marriage or civil partnership formation increases to four years. However it is too early to say whether this trend will continue beyond the fourth anniversary.

Many people were keen to form a civil partnership soon after the legislation came into effect in December 2005; some of them had been in a relationship for some time and would have formed a civil partnership earlier, had that been possible. The impact of this phenomenon on the percentage 
of civil partnerships dissolved could distort these percentages in the short term, so a longer time series is required for a fuller comparison.

\section{Table 3 Percentage of civil partnerships dissolved by year of formation}

\begin{tabular}{llcccc}
\hline \multirow{2}{*}{$\begin{array}{l}\text { Year of civil } \\
\text { partnership }\end{array}$} & $\begin{array}{l}\text { Number of } \\
\text { civil }\end{array}$ & \multicolumn{4}{c}{$\begin{array}{l}\text { Percentage dissolved by } \\
\text { anniversary (years) }\end{array}$} \\
& partnerships & $\mathbf{1}$ & $\mathbf{2}$ & $\mathbf{3}$ & $\mathbf{4}$ \\
\hline $\mathbf{2 0 0 5}$ & 1,857 & 0.0 & 0.6 & 1.2 & 2.5 \\
$\mathbf{2 0 0 6}$ & 14,943 & 0.0 & 0.5 & 1.7 & \\
$\mathbf{2 0 0 7}$ & 7,929 & 0.0 & 0.7 & & \\
$\mathbf{2 0 0 8}$ & 6,558 & 0.0 & & & \\
\hline
\end{tabular}

\section{Table 4 Percentage of marriages ending in divorce by year of marriage}

\begin{tabular}{llcccc}
\hline $\begin{array}{l}\text { Year of } \\
\text { marriage }\end{array}$ & $\begin{array}{l}\text { Number } \\
\text { of } \\
\text { marriages }\end{array}$ & \multicolumn{4}{c}{$\begin{array}{l}\text { Percentage divorced by } \\
\text { anniversary (years) }\end{array}$} \\
$\mathbf{2 0 0 5}$ & 247,805 & 0.0 & $\mathbf{2}$ & $\mathbf{3}$ & $\mathbf{4}$ \\
$\mathbf{2 0 0 6}$ & 239,454 & 0.0 & 0.9 & 3.1 & 5.5 \\
$\mathbf{2 0 0 7}$ & 235,367 & 0.0 & 0.8 & & \\
$\mathbf{2 0 0 8}$ & 235,794 & 0.0 & & & \\
\hline
\end{tabular}

\section{Estimating the stock of civil partners living in England and Wales}

Figure 10 shows estimates of the stock of civil partners in England and Wales between 2006 and 2010. The stock shows the number of people living in England and Wales who are civil partners, rather than the number of people who are forming a civil partnership each year. Box $\mathbf{3}$ shows how to calculate this stock.

The estimate of civil partners living in England and Wales is consistently lower using registration data than using surveys, except in 2010 where the LFS and registration data are similar. For example, in 2009 the estimated stock of civil partners from registration data was 68,000, whereas it was 78,000 according to the LFS and 88,000 according to the APS. However the estimates from the survey sources and registration data are only significantly different in 2007 (where there is no overlap between the LFS confidence intervals and the registration estimate). It is also noticeable that the estimates start lower in 2006 using registration data, but follow a similar level of increase as the survey sources. Possible reasons for the differences include:

- The estimates from registration data assume that there was no one living in England and Wales in a civil partnership before civil partnership formation became legal in December 2005.

However, the finding that the estimate from registration data is lower than from the surveys in 2006 suggests that some people may have formed civil partnerships abroad before 2006

- The registration estimates exclude civil partnerships formed in Scotland, Northern Ireland or abroad since December 2005, unless they are also registered in England and Wales. A large 
number of England and Wales residents travel abroad to get married each year ${ }^{17}$, so this is also likely to be the case among those forming civil partnerships. For example, civil partnerships formed in Canada, South Africa and New Zealand can be legally recognised in the UK

- Civil partnerships dissolved outside England and Wales cannot be accounted for in the registration estimate, nor can deaths of civil partners outside England and Wales

- Although international migration of civil partners is accounted for in the registration estimate, the International Passenger Survey does not provide very robust estimates of the number of civil partners migrating due to small sample sizes

- Survey estimates exclude civil partners living in most communal establishments as the surveys only cover the population living in private households, NHS accommodation and students in halls of residence whose parents live in the UK

- Survey estimates are subject to sampling error. For example we can be 95 per cent sure that the 2006 LFS estimate of the number of civil partners is between 14,000 and 33,000 and that the 2010 estimate is between 63,000 and 102,000

\section{Figure 10 Estimates of the stock of civil partners living in England and Wales, 2006-2010 (thousands)}

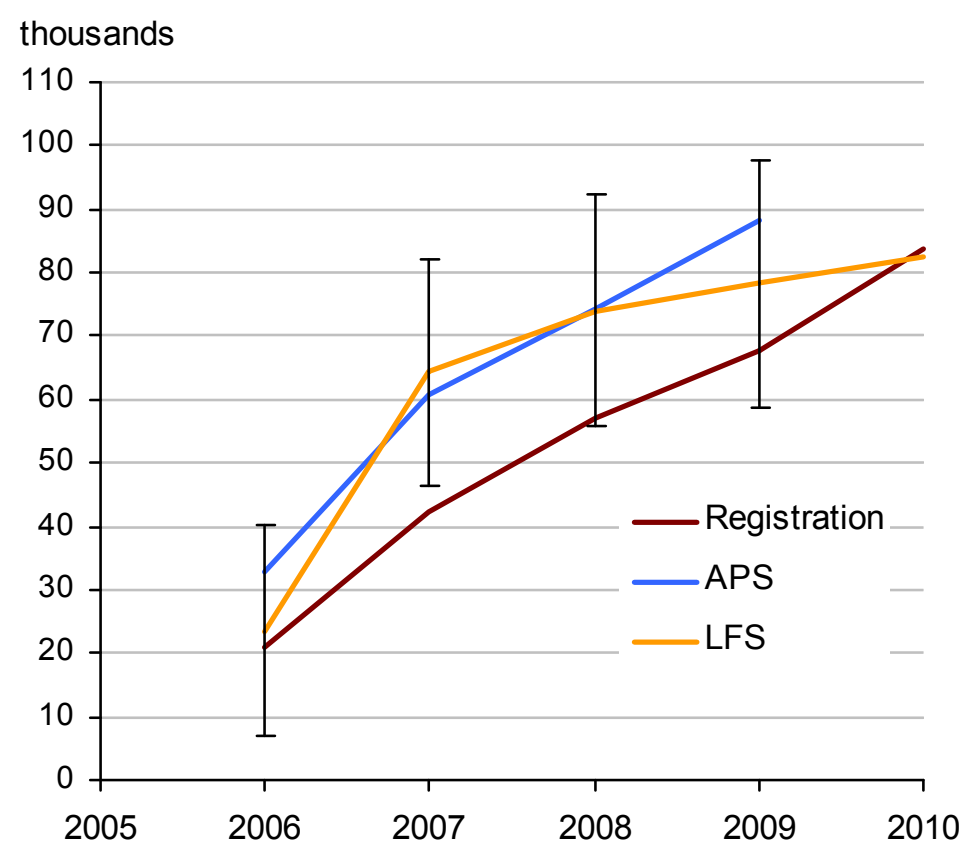

Note: The marital status question in the LFS and APS household datasets was used for this analysis, and 95 per cent confidence intervals are shown around the LFS estimates. The latest APS calendar year data available were for 2009. Estimates of international migration and civil partnership dissolution for 2010 used in the registration estimate are provisional. In addition, data on deaths for 2010 (used in the registration estimate) are based on registrations, whereas for 2006-2009 they are based on occurrences.

Source: Office for National Statistics

Box 3 describes how registration data was used to estimate the stock of civil partners in England and Wales. This same method has been used to calculate the stock of former civil partners whose relationship has been legally dissolved. In 2008, there were estimated to be around 170 people whose civil partnership had been dissolved, rising to around 759 such people in 2010 . These 
figures are expected to increase over time. Neither the Labour Force Survey nor the Annual Population Survey provides robust estimates of the number of civil partners whose partnership has been dissolved due to the small sample size of this group.

\section{Box 3 Calculating an estimate of the stock of civil partners from registration and survey sources}

\section{Registration sources}

Stock of civil partners in year $y=$ stock of civil partners in year $(y-1)$

+ people forming civil partnerships in year y

- people dissolving civil partnerships in year y

- deaths of civil partners in year $y$

+ international immigration of civil partners in year $y$

- international emigration of civil partners in year $\mathrm{y}$.

The stock estimate before 2005 is assumed to be zero. Immigration and emigration data come from the International Passenger Survey, a survey of a random sample of passengers entering and leaving the UK by air, sea or the Channel Tunnel. Estimates from registration data are for 30 June each year.

\section{Survey sources}

Estimates are based on the Annual Population Survey (APS) and the Labour Force Survey (LFS).

The LFS is a household survey of people in the UK. It covers people in private households, NHS accommodation and students in halls of residence whose parents live in the UK. The key purpose of the LFS is to provide information on the UK labour market but it includes data on a variety of other variables such as marital/civil partnership status. The estimates shown here are based on the April to June quarter each year. The APS is created by combining results from the LFS and the English, Welsh and Scottish LFS boosts.

\section{Estimating the number of children of civil partners}

Like children living with married couples, children living with civil partners may have been born within the partnership, born to one partner in a previous relationship or adopted by one or both partners. There are several sources of data that give part of the picture with regard to children living with civil partners. These are outlined below, along with their limitations.

\section{Births registered to civil partners}

The Human Fertilisation and Embryology Act $2008^{18,19}$ contained provisions enabling two women in a same-sex couple ${ }^{20}$ to register a birth where the birth occurred in the UK. The new law applied 
to fertility treatments carried out on or after 6 April 2009, with the birth being registered on or after 1 September 2009. Prior to 1 September 2009, births to female same-sex couples resulting from fertility treatment would most likely have been registered by the mother alone.

Between 1 September 2009 and 31 December 2009 there were 24 live births registered in England and Wales to females in same-sex couples. The majority of these births (22) were to females in a civil partnership, with only two births registered to same-sex couples outside of a civil partnership. During 2010, the first complete calendar year with the new law in place, there were 475 live births registered in England and Wales to same-sex couples. Of these, 335 births (71 per cent) were registered to females in a civil partnership.

The Human Fertilisation and Embryology Act 2008 also enabled two men in a same-sex couple to obtain a parental order through the courts to be officially registered as the parents post-registration. These changes have brought the UK's fertility law into line with equalities legislation by giving same-sex couples the same rights to parenthood as opposite sex couples when registering their child's birth. It is not possible to determine how many birth registrations are amended to have two males officially registered as the parents because birth statistics collated and published by the Office for National Statistics (ONS) do not take account of re-registrations.

\section{Adoption by same-sex couples}

Although lesbian, gay and bisexual people had previously been able to adopt as individuals, the Adoption and Children Act (2002) which came into effect in December 2005 legalised adoption for same-sex couples. This means that such people are now able to apply for joint adoption proceedings with both partners obtaining parental rights. ONS does not hold data on the number of adoptions of children by same-sex couples but the Department for Education publish information on the number of same-sex couples adopting children ${ }^{21}$. The Human Fertilisation and Embryology Act 2008 and the Civil Partnership Act 2004 have also made it easier for lesbian couples to secure parental rights for any children they conceive through artificial insemination.

\section{Civil partnership couples with dependent children}

The number of civil partnership couples with children sampled in surveys is very small so it is very difficult to make precise estimates. Estimates from the Labour Force Survey show that there were around a thousand civil partner couple families with dependent children ${ }^{22}$ in England and Wales in 2010. However, given the small number of people in this situation sampled, the 95 per cent confidence interval for this estimate is between zero and three thousand. Around seven per cent of all civil partner couples had dependent children living with them and this estimate has remained largely stable since 2007. On average between 2007 and 2010, civil partners with dependent children had 1.5 dependent children and around four fifths of civil partners with dependent children were women. Not all children will have been born within the civil partnership; many will be from one partner's previous relationships and/or adopted.

UK estimates of civil partnership couples and same-sex cohabiting couples with and without children are published on the ONS website ${ }^{23}$. 


\section{Attitudes towards same-sex partnerships and civil partnerships in Great Britain and Europe: Evidence from recent survey data}

Changes in legislation can both promote and respond to changes in public opinion. In this section we examine trends and patterns in public opinion concerning same-sex couples and civil partnerships and compare attitudes in Great Britain with other European countries. See Box $\mathbf{4}$ for details of the data sources used and the Appendix for details of the question wording. We start by examining the trend between 1983 and 2007 in the reported acceptability of sexual relations between two adults of the same sex.

\section{Box 4 Sources of data on attitudes to same-sex partnerships and civil partnerships}

Information on public attitudes to same-sex couples has been collected within the British Social Attitudes Survey (BSA), run by the National Centre for Social Research, in the years 19832007. (The wording of the question which comes at the end of three questions on sexual morality is shown in the Appendix). The question wording changed in 2008.

One of the most recent sources of information concerning attitudes to civil partnerships in Great Britain is the 2008 BSA. Two slightly different questions concerning the legalisation of samesex partnerships were posed to two different halves of the sample. A further question on the rights of same-sex couples to adopt children is also shown in the Appendix. The analyses presented here are weighted using survey weights provided by the survey team. For details of the survey see Park et al $(2010)^{24}$.

One source of comparative European data on attitudes to the legal status of same-sex partnerships is the Eurobarometer survey. Eurobarometer is run by TNS Opinion and Social on behalf of the European Commission. In 2006 two questions were asked to around a thousand respondents from each of the EU25 countries ${ }^{25}$. Given the small sample sizes for each country the results can only be indicative of the main differences and general ordering of countries. The data are weighted using the EU25 weights provided by the survey team. The two questions addressed the following statements: 1) Homosexual marriages should be allowed throughout Europe 2) Adoption of children should be authorised for homosexual couples throughout Europe.

\section{Attitudes in Great Britain}

Figure 11 shows how the percentage of people in Great Britain who view sexual relations between two adults of the same-sex as 'always wrong' or 'mostly wrong' increased during the mid 1980s (during the peak of AIDS campaigns and media interest) to almost three quarters of the population, before falling to less than half. In comparison, the percentage who think that same-sex partnerships are 'rarely wrong' or 'not wrong at all' has increased since the mid 1980s, overtaking those who think they are 'always or mostly wrong' in the early 2000s. As documented previously ${ }^{26,27,28}$, these changes in attitudes have come about largely as a result of earlier cohorts with more traditional views being replaced by later cohorts with more liberal views. 
In 2008, there remained very large differences in the public's attitude to laws that make same-sex partnerships more like marriage. Among those aged 18-29 almost one half approved or strongly approved of such laws compared to less than 20 per cent of those aged 70 and over (Figure 12 from GAYMARR question, see Appendix). Comparison by sex suggests that women are more approving of laws that provide same-sex partnerships more marriage rights than men. Even among the youngest age group, one in five men disapproved or strongly disapproved of such laws compared with one in eight women.

\section{Figure 11 Trends in acceptance of 'sexual relations between two adults of the same-sex', 1983-2008. Great Britain.}

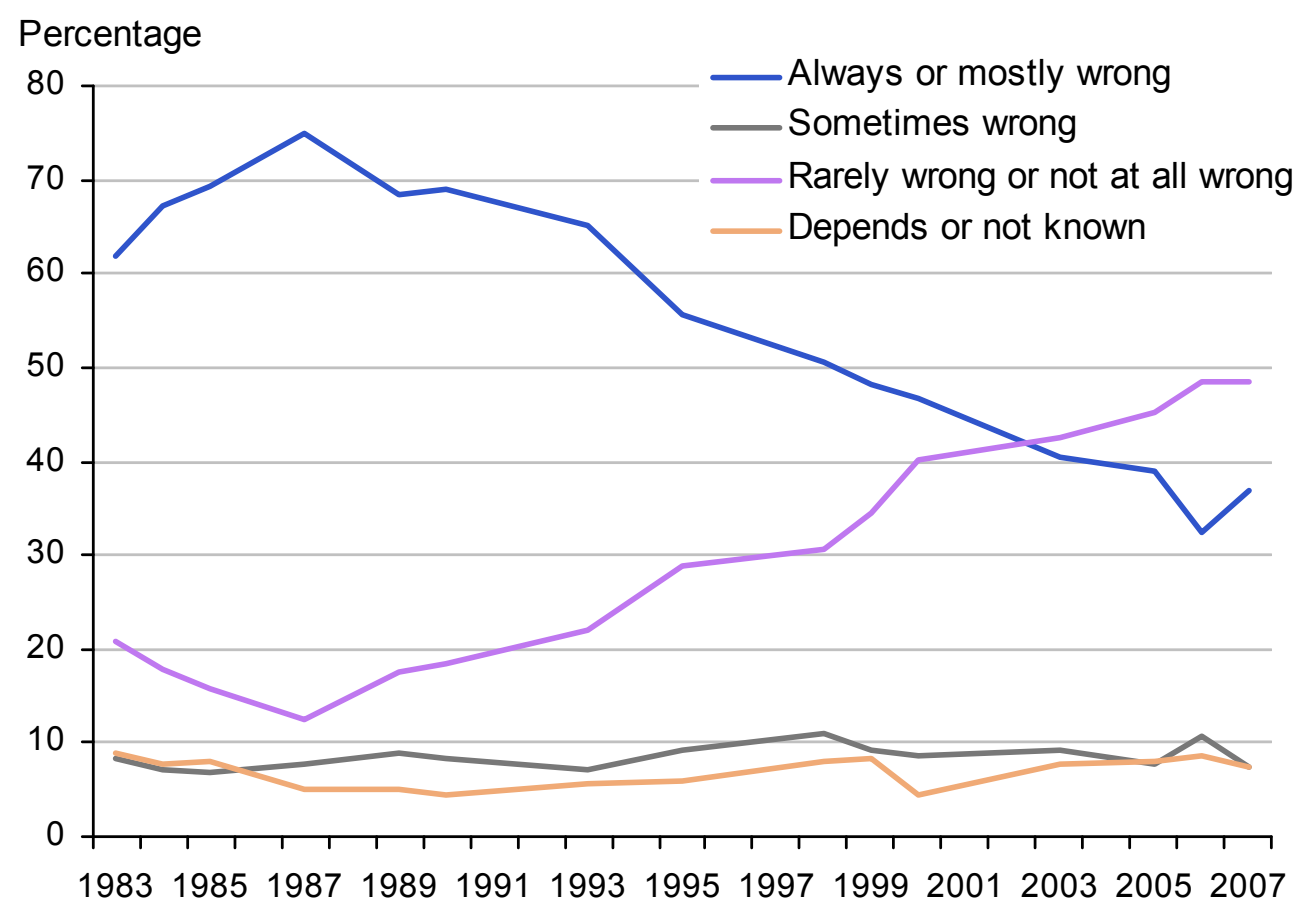

Source: British Social Attitudes Survey, 1983-2007 
Figure 12 Approval of 'laws that treat same-sex partnerships somewhat like marriage', by age, (a) men (b) women, 2008. Great Britain.

Fig. 12a Men

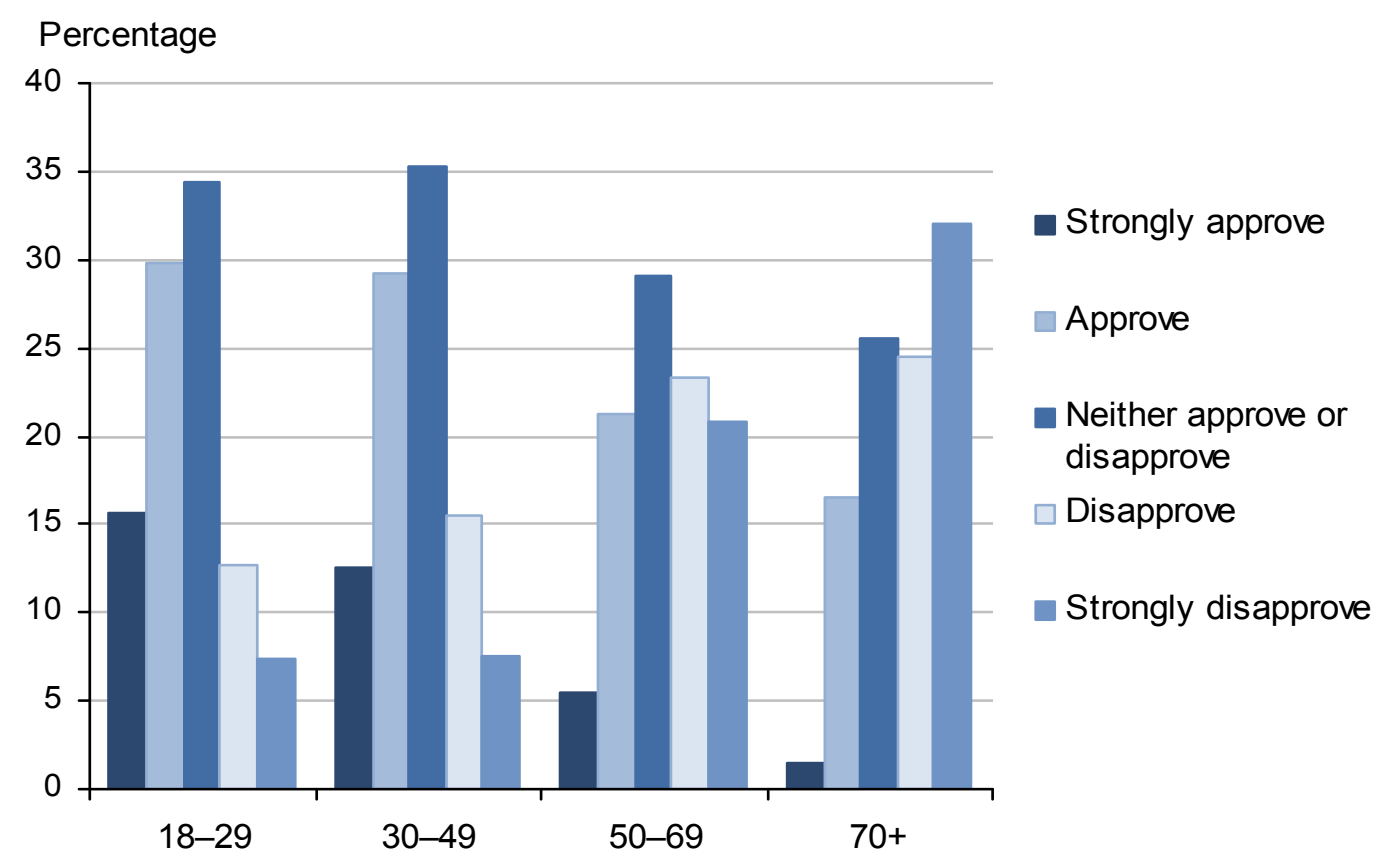

Source: British Social Attitudes Survey, 2008

Fig. 12b Women

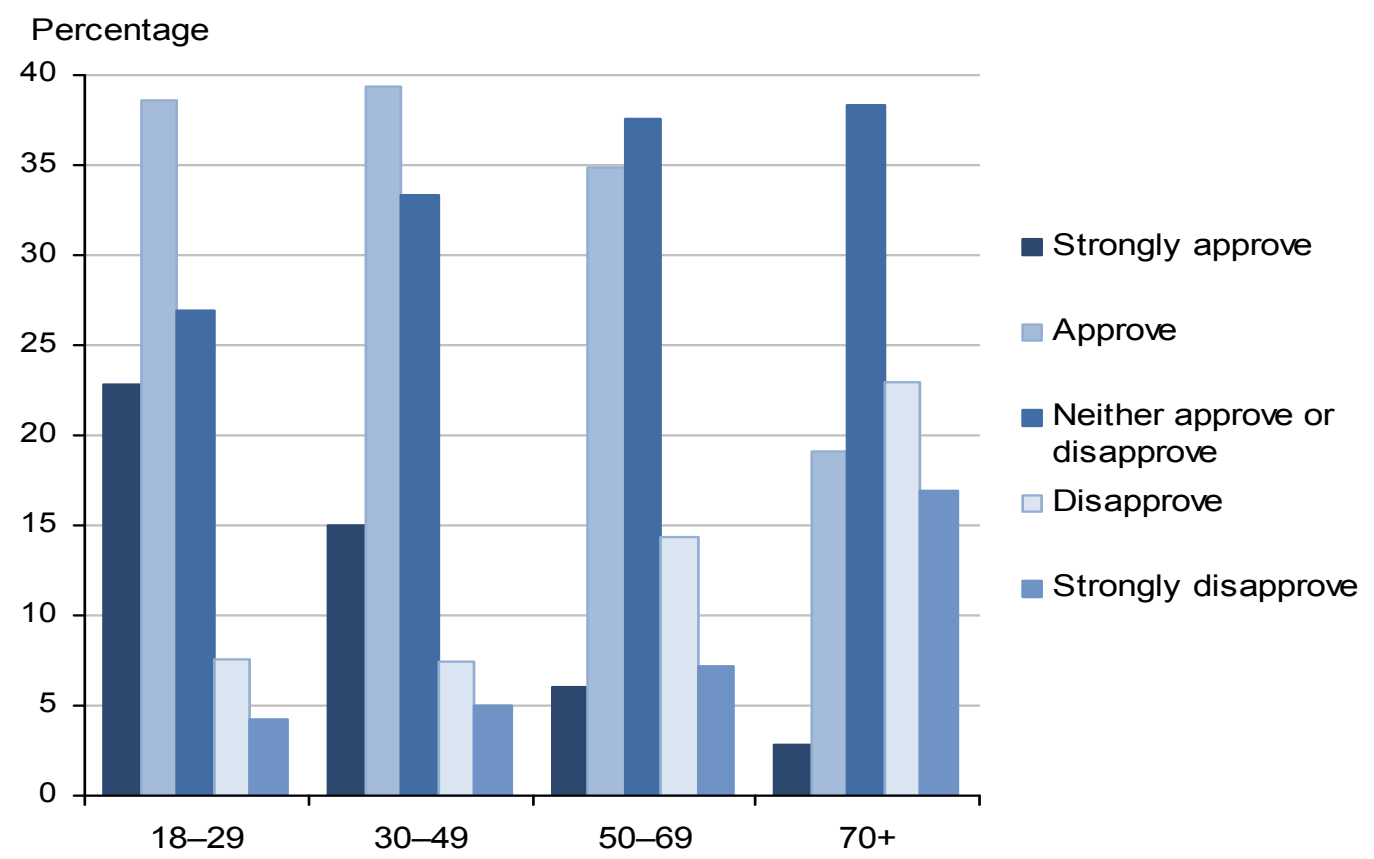

Source: British Social Attitudes Survey, 2008 
The BSA respondents who were posed the alternative question regarding the ability of same-sex couples to obtain legal recognition (from GAYCOUP question, see Appendix) provide results which are very consistent (Figure 13).

\section{Figure 13 Views about how same-sex couples should be treated in law, by age, (a) men (b) women, 2008. Great Britain.}

Fig. 13a Men

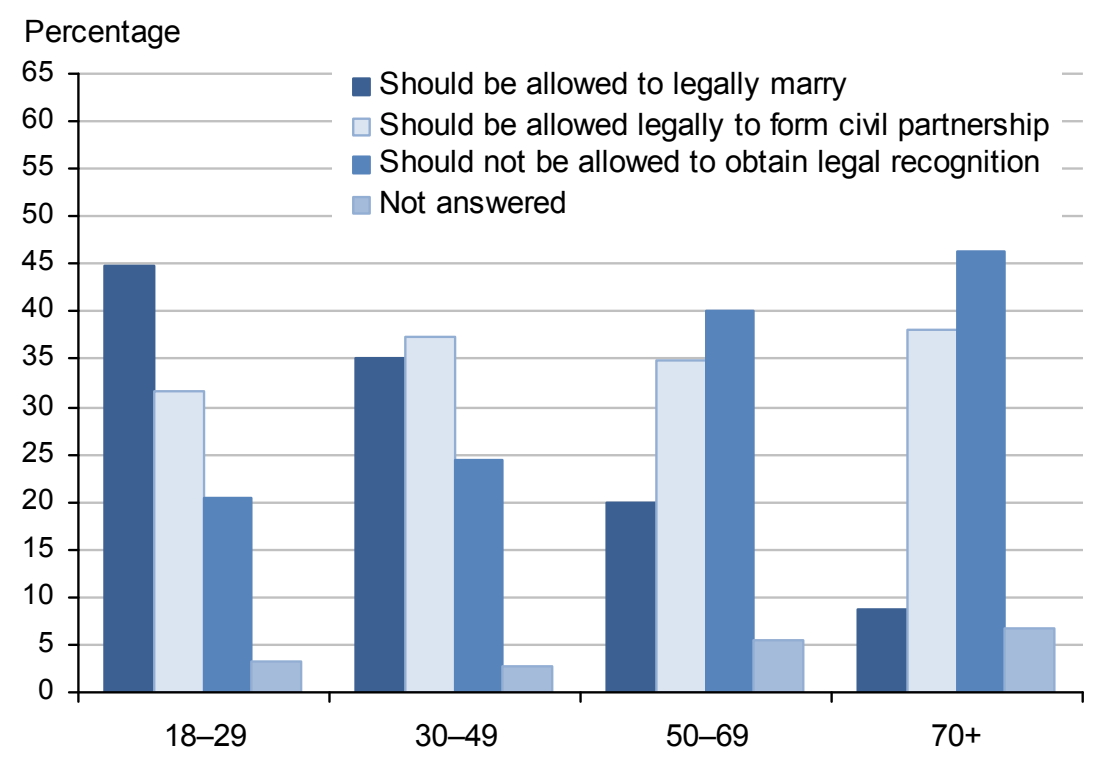

\section{Fig. 13b Women}

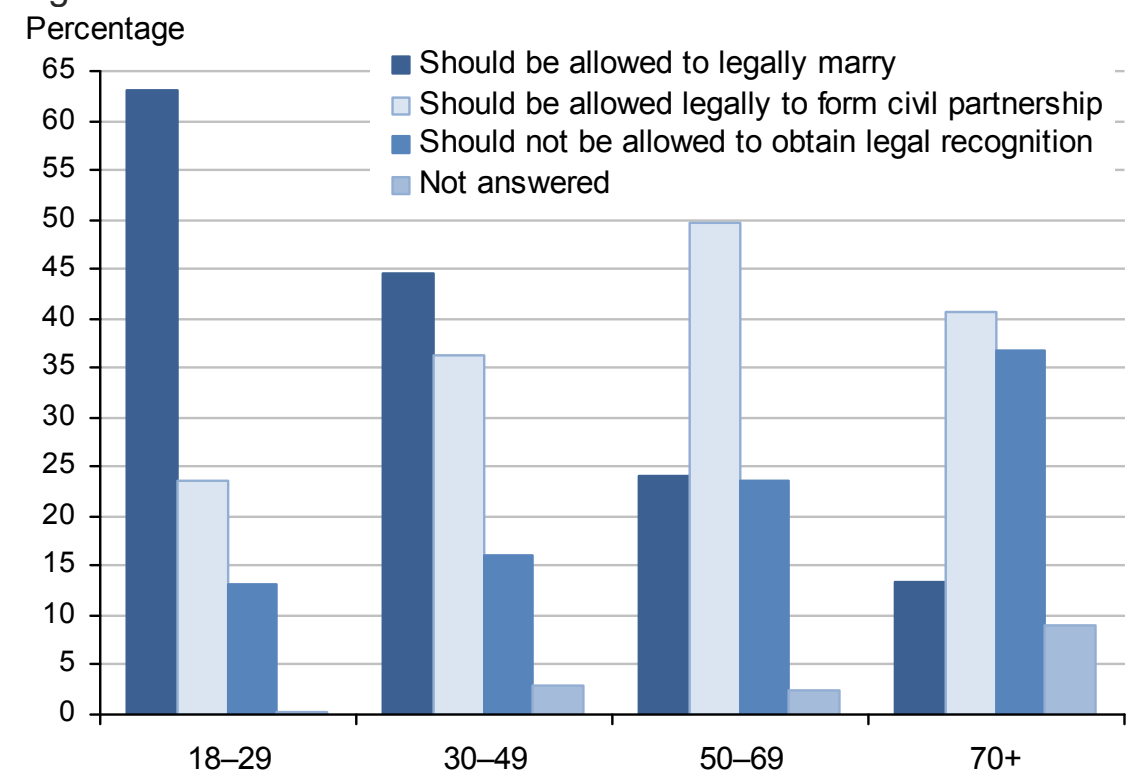

Source: British Social Attitudes Survey, 2008

Again there are significant differences according to age and sex. The oldest age group (70+) tended to reject the idea that same-sex couples should be allowed to marry with over a third of men and women aged 70+ responding that same-sex couples should not be allowed to obtain any legal recognition for their relationship. In contrast, the younger age groups were far more accepting 
of the idea that same-sex couples should be allowed legal recognition and many were supportive of allowing same-sex couples to marry, although there are significant sex differences. Among women aged 18-29, around 60 per cent thought that same-sex couples should be allowed to marry compared to only 45 per cent of young men. Sex differences are smaller among those in middle age. For example, among those aged 30-49, 35 per cent of men and 43 per cent of women thought that same-sex couples should be allowed to marry.

\section{Figure 14 Approval of 'allowing same-sex couples to adopt children',} by age, (a) men (b) women, 2008. Great Britain.

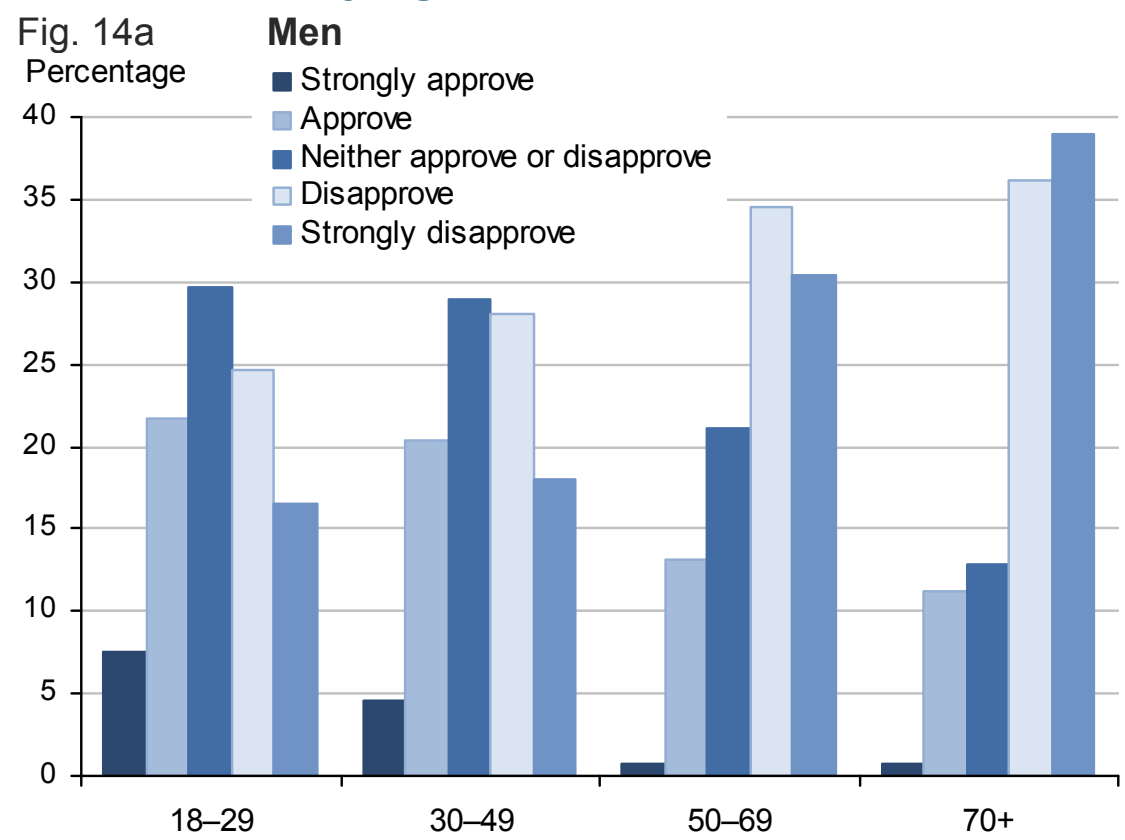

Fig. 14b Women

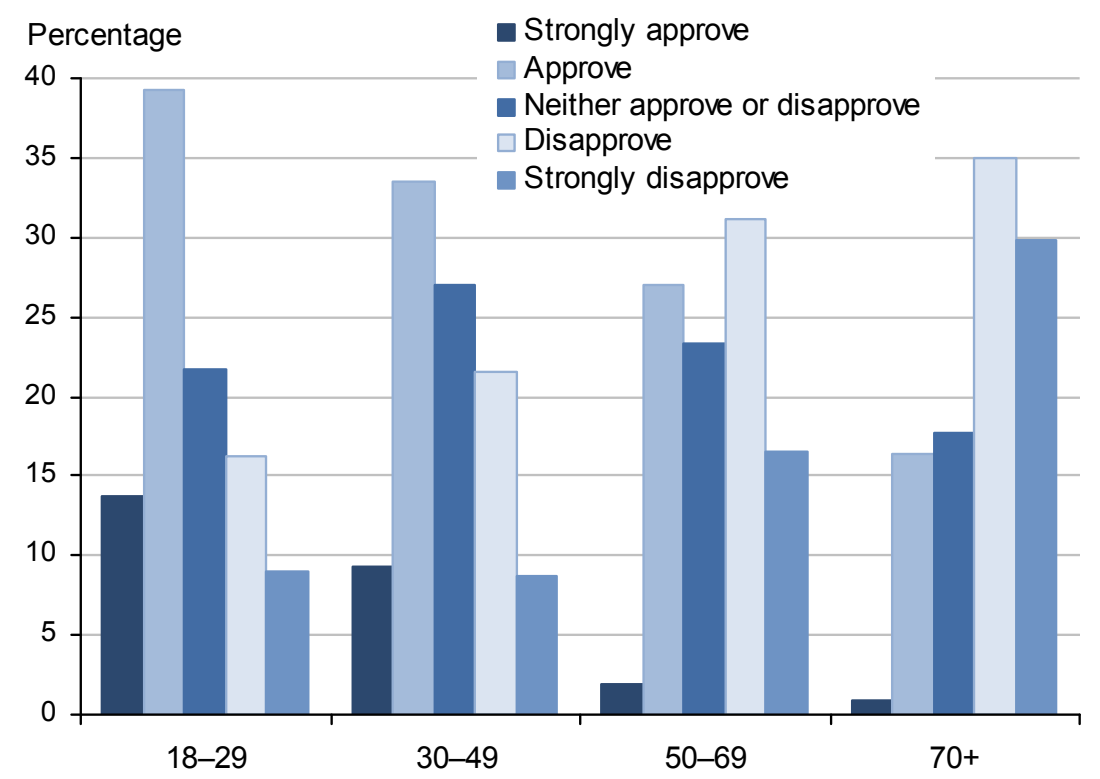

Source: British Social Attitudes Survey, 2008 
While the majority of British people now accept the concept of same-sex couples as being rarely wrong or not wrong at all, fewer people approve of same-sex couples adopting children (Figures $14 \mathrm{a}$ and 14b). Even among the youngest age group, only 30 per cent of men and 50 per cent of women approve (GAYCHLD question). Once again there are significant differences according to age, with virtually none of those aged $70+$ strongly approving of same-sex adoption.

\section{Attitudes in Europe}

The attitudes of UK men and women compared with their European counterparts in 2006 are examined next. Figure 15 shows the percentage who strongly agreed or agreed with the statement that 'homosexual marriages should be allowed throughout Europe'.

\section{Figure 15 Percentage who agree that 'homosexual marriages should be allowed throughout Europe'. EU25 2006.}

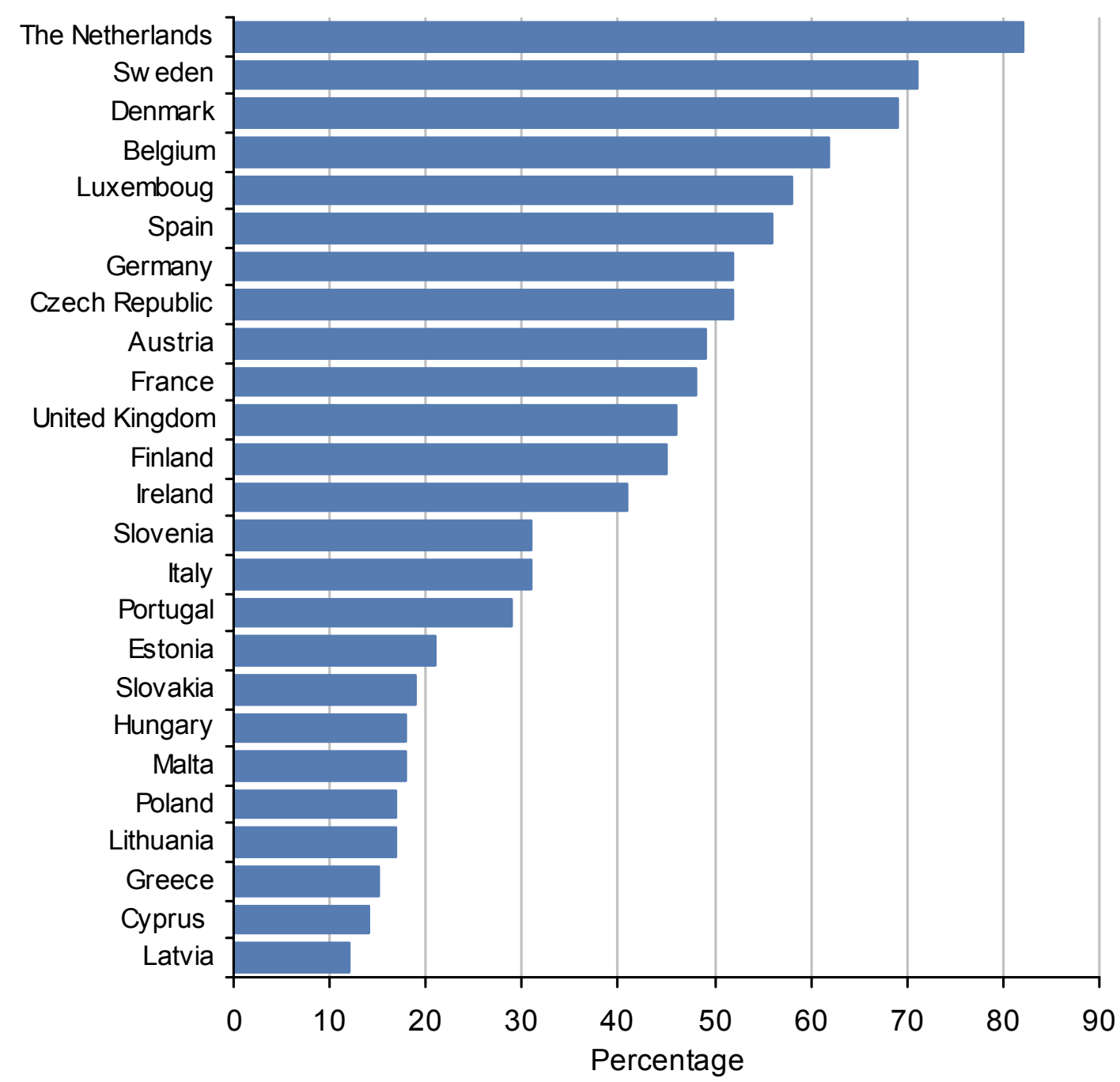

Source: EC Eurobarometer 66.1

The most liberal attitudes were found in the Netherlands where around 85 per cent of the population agreed. More positive attitudes to homosexual marriage were also found in Denmark, 
Sweden, Belgium, Luxemburg and Spain, all countries which have recently legalised same-sex marriages. Medium levels of support for same-sex marriage were found in the UK along with countries such as Germany, France and Finland. Lower levels of support were found in Malta, Poland, Greece, Cyprus and Latvia.

\section{Figure 16 Percentage who agree that 'adoption of children should be authorised for homosexual couples throughout Europe'. EU25 2006.}

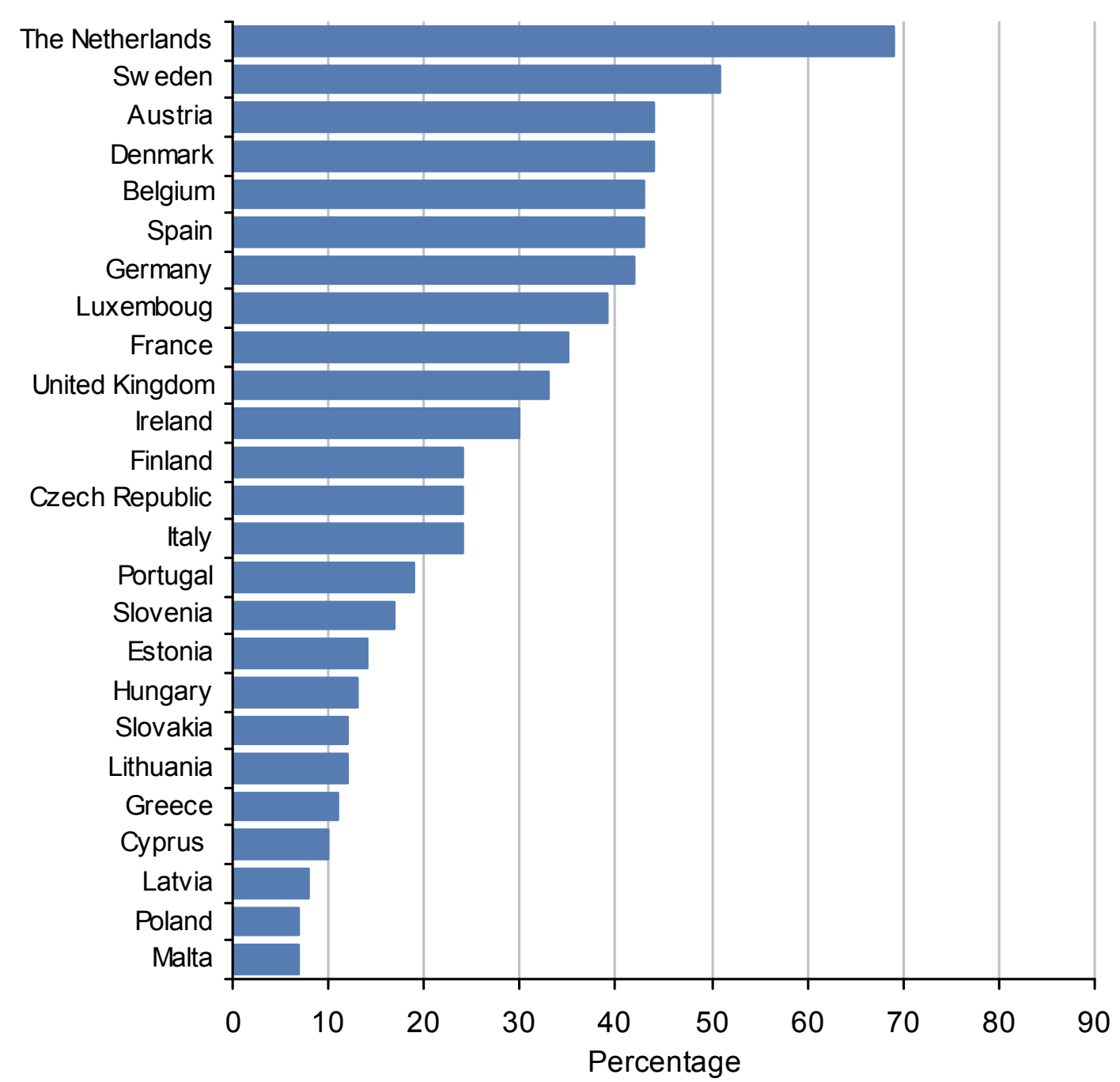

Source: EC Eurobarometer 66.1

Across Europe, support for the ability of same-sex couples to adopt children was somewhat lower (Figure 16). The Netherlands stood apart with over two thirds supporting gay adoption. In all other European countries around half or less were supportive. The relative ordering of countries was similar to that seen earlier for the support of same-sex marriage, with the UK being intermediate and having around one third of the adult population in support of allowing same-sex couples the ability to adopt. 


\section{Summary and discussion}

The Civil Partnership Act was introduced in December 2005. The number of civil partnerships in England and Wales peaked immediately after the Act came into force. Many couples are likely to have waited years to formalise their relationship and therefore chose to do so after civil partnerships became legally recognised. Initially a higher proportion of civil partnerships involved men but currently the numbers of newly formed male and female civil partnerships are roughly equal.

Average ages at civil partnership formation have decreased in recent years but there remains a tendency for the average age at civil partnership formation to be greater than for entry into marriage and for the age difference between civil partners to be greater than that for marriage partners.

Early figures suggest that marriages are more likely to end in divorce than civil partnerships are to end in dissolution, although this may be distorted by a high proportion of civil partnerships being formed initially to couples who had already been together a significant time. A longer time series will enable better analysis of this, and other comparisons, between civil partnerships and marriages. ONS will continue to monitor and report on the trends in civil partnerships and samesex couples.

While the majority of British people now accept the concept of same-sex couples as being 'rarely wrong' or 'not wrong at all', fewer people approve of same-sex couples adopting children. On average females have more liberal attitudes to same-sex partnerships than males. Younger people tend to have more liberal attitudes and future increases in the acceptance of same-sex relationships and civil partnerships seems likely as older birth cohorts die.

In February 2011 the Coalition Government announced its commitment to enable civil partnerships to be registered on the religious premises of faith groups who wished to host them. This will be implemented by removing the legal prohibition on civil partnerships being registered on religious premises using section 202 of the Equality Act $2010^{29}$. It may be possible for religious premises to become licensed for the purpose of holding civil partnerships by the end of 2011 .

\section{Acknowledgements}

The authors would like to thank Julie Jefferies and Nicola Haines of the Office for National Statistics whose valuable advice and comments greatly improved this article. The contribution of Berrington is funded by ESRC Grant number RES-625-28-0001. The Centre for Population Change (CPC) is a joint initiative between the University of Southampton and a consortium of Scottish Universities in partnership with ONS and NRS. Access to the Eurobarometer 66.1 Survey: European Values and Societal Issues, Mobile Phone Use, and Farm Animal Welfare SeptemberOctober 2006 (ZA4526) is via GESIS - The Leibniz Institute for the Social Sciences. The British Social Attitudes Survey is carried out by the National Centre for Social Research and access to the data is provided by the UK Data Archive. The original data creators, depositors and copyright holders bear no responsibility for this analysis or interpretation. 


\section{Key findings}

- The number of civil partnerships in England and Wales peaked immediately after the Civil Partnership Act 2004 came into force. Many couples are likely to have waited years to formalise their relationship and therefore chose to do so after civil partnerships became legally recognised

- In December 2005 and the first quarter of 2006, two thirds of civil partnerships were to male couples. This proportion gradually decreased. By 2010 more women than men formed civil partnerships

- Males are on average older than females when they enter into a civil partnership

- The average age of those who have registered a civil partnership so far is considerably higher than that for marriage but has been decreasing

- The number of civil partnership dissolutions has increased year on year since 2007

- Early figures suggest that marriages are more likely to end in divorce than civil partnerships are to end in dissolution, although this may be distorted by a high proportion of civil partnerships being formed initially to couples who had already been together a significant length of time

- Around seven per cent of all civil partner couples living in England and Wales had dependent children in 2010, many of whom will be from one partner's previous relationships and/or adopted

- Differences in attitudes towards same-sex partnerships vary by age and sex. Recent changes in attitudes have partly been driven by earlier cohorts with more traditional views being replaced by later cohorts with more liberal views

- While the majority of British people now accept the concept of same-sex couples as being 'rarely wrong' or 'not wrong at all', fewer people approve of same-sex couples adopting children

- People living in European countries which have recently legalised same-sex partnerships are likely to have more positive attitudes to homosexual marriage than those in countries where there is no such law

A Video podcast summarising the contents of this article is available at: www.youtube.com/user/onsstats

\section{Notes and References}

1 Civil Partnership Act 2004 available at: www.legislation.gov.uk/ukpga/2004/33/contents

2 Information on forming a civil partnership is available at:

www.direct.gov.uk/en/Governmentcitizensandrights/Registeringlifeevents/Marriagesandcivilp artnerships/DG 175715

3 Digoix, M. (2004) Paths towards equality. Pp 1-19 in M. Digoix and P. Festy (eds) Same Sex Couples, Same Sex Partnerships and Homosexual Marriages. A focus on cross-national differences. Paris: INED. www.ined.fr/fichier/t publication/1035/publi pdf1 124.pdf 
4 Shipman, B and Smart, C (2007) 'It's Made a Huge Difference': Recognition, Rights and the Personal Significance of Civil Partnership. Sociological Research Online Vol 12 (1) www.socresonline.org.uk/12/1/shipman.html

5 Waaldijk, K. (2004) Levels of consequences of marriage, cohabitation and registered partnership for different-sex and same-sex partners: Comparative overview and comparative analysis. Pg 47-92 in M. Digoix and P. Festy (eds) Same Sex Couples, Same Sex Partnerships and Homosexual Marriages. A focus on cross-national differences. Paris: INED. www.ined.fr/fichier/t publication/1035/publi pdf1 124.pdf

Adoption and Children Act 2002 available at: www.legislation.gov.uk/ukpga/2002/38/contents

7 The latest civil partnerships data is available on the ONS website at: www.ons.gov.uk/ons/rel/vsob2/civil-partnership-statistics--united-kingdom/2010/index.html

8 Regulatory Impact Assessment on the Civil Partnership Act 2004 available at: www.equalities.gov.uk/pdf/Final\%20Regulatory\%20Impact\%20Assessment $\% 20$ \%20Civil\%20Partnership\%20Act\%202004.pdf

9 This compares with a provisional total of 92,170 civil partners in Great Britain by 2010 .

10 Andersson, G, Noack, T, Seierstad, A and Weedon-Fekjaer H (2006) 'The Demographics of Same-Sex Marriages in Norway and Sweden, Demography 43: 79-98

11 Rates are based on the number of people forming a civil partnership per year as a proportion of the population legally able to form a civil partnership (the population at risk). Here, the population at risk is defined as the number of men or women aged 16 and over living in England and Wales, irrespective of sexual identity, who are not currently married. Ideally, the population at risk should exclude those that are already in a civil partnership; however civil partnership status is not included in the mid-year population estimates by marital status. Rates for 2005 have been adjusted to take account of the fact that there were only 11 days in England and Wales on which couples could register a civil partnership.

12 Rates for 2010 are based on mid-2009 marital status estimates and are therefore provisional

13 The mean ages are not standardised and therefore take no account of the structure of the population by age or partnership status.

14 Mid-year population estimates available at: www.ons.gov.uk/ons/search/index.html?contenttype=Reference+table\&pubdateRangeType=allDates\&newquery $=\% 27 \mathrm{Mid}-$ year+population+estimates $\% 27 \&$ pageSize $=50 \&$ applyFilters $=$ true

15 The term dissolution in this article refers to both civil partnership dissolutions and annulments.

16 Like marriages, civil partner couples must wait a year after formation to legally file for dissolution of their relationship.

17 See 'Methodology to adjust mid-year population estimates by marital status for marriages abroad' at www.ons.gov.uk/ons/rel/pop-estimate/population-estimates-by-marital-status/mid2007/marital-status-2002-2007-marriages-abroad.pdf 
18 Human Fertilisation and Embryology Act 2008 available at:

www.legislation.gov.uk/ukpga/2008/22/contents

19 Information on the recent legal changes of the Human Fertilisation and Embryology Act 2008 which affect same-sex couples are available at:

www.stonewall.org.uk/at home/parenting/3601.asp

20 Under the HFEA, the term 'same-sex couple' refers to civil partners or two persons of the same-sex living as partners in an enduring family relationship and are not within prohibited degrees of relationship in relation to each other.

21 Data on the number of same-sex couples adopting children www.education.gov.uk/rsgateway/DB/SFR/s000960/index.shtml

22 Dependent children are those living with their parent(s) and either (a) aged under 16, or (b) aged 16 to 18 in full-time education, excluding children aged 16 to 18 who have a spouse, partner or child living in the household.

23 Estimates of same-sex cohabiting couples and civil partnership couples with and without children: www.ons.gov.uk/ons/rel/family-demography/families-and-households/2001-to2010/index.html

24 Park, A., Curtice, J., Thomson, K., Phillips, M.,Clery, E and Butt, S (eds.) (2010) British Social Attitudes: the 26th Report, London: Sage. See: www.natcen.ac.uk/study/british-socialattitudes-26th-report/our-findings

25 European Commission (2006) Eurobarometer 66. Public Opinion in the European Union. First Results. Available from: http://ec.europa.eu/public opinion/archives/eb/eb66/eb66 highlights en.pdf

26 Berrington, A. and Smith, P.W.F. (2009) Sexual morality and family attitudes in Britain: The role of cohort replacement and period effects in attitudinal change. Paper prepared for International Union for the Scientific Study of Population International Conference. Marrakech, 27 September - 2 October 2009. iussp2009. princeton.edu/download.aspx?submissionld=93113

27 Crockett, A. and Voas, D. (2003) A divergence of views: Attitude change and the religious crisis over homosexuality. Sociological Research Online, 8(4). Available from: www.socresonline.org.uk/8/4/crockett.html

28 Duncan, S. and Phillips, M. (2008) 'New families? Tradition and change in partnering and relationships' in British Social Attitudes 2007/8, London, NatCen, Sage. See: www.downloadit.org/free files/Pages $\% 20$ from $\% 201 \% 20 \mathrm{New} \% 20$ families $\% 20$ \%20Tradition $\% 20$ and $\% 20$ change $\% 20$ in $\% 20$ modern $\% 20$ relationshipsa66360060de47b7b96168bcae6241ed1.pdf

29 Equality Act 2010 available at: www.legislation.gov.uk/ukpga/2010/15/contents 


\section{Appendix}

Question on same sex couples asked regularly between 1983 and 2007 in the British Social Attitude Survey.

\section{HOMOSEX}

Now I would like to ask you some questions about sexual relationships. What about sexual relations between two adults of the same sex? What would your general opinion be?

1 Always wrong

2 Mostly wrong

3 Sometimes wrong

4 Rarely wrong

5 Not wrong at all

6 Depends/varies

\section{Questions regarding civil partnerships from 2008 British Social Attitude Survey.}

GAYMARR

Some people live with partners of the same sex. Using this card please say whether you approve or disapprove of laws that treat these partnerships somewhat like marriage.

1 Strongly approve

\section{Approve}

3 Neither approve nor disapprove

4 Disapprove

5 Strongly disapprove

8 Don't know

9 Refusal

GAYCHLD

And do you approve or disapprove of allowing same-sex couples to adopt children?

1 Strongly approve

2 Approve

3 Neither approve nor disapprove

4 Disapprove

5 Strongly disapprove

8 Don't know

9 Refusal

Note that a very small number (less than $1 \%$ of the sample) refused to answer these questions or did not know (codes 8 and 9). These are deleted from the analysis.

GAYCOUP.

Which of these statements comes closest to your view about how same sex couples should be treated in law?

PLEASE TICK ONE BOX ONLY

Should be allowed legally to marry [1]

Should be allowed legally to form civil unions, but not marry [2]

Should not be allowed to obtain legal recognition for their relationships [3] 